by Camille François ${ }^{1 *}$, Manuel Pubellier ${ }^{1,2 *}$, Christian Robert ${ }^{2}$, Cédric Bulois ${ }^{2,3}$, Siti Nur Fathiyah

\title{
Temporal and spatial evolution of orogens: a guide for geological mapping
}

\author{
${ }^{1}$ Commission for the Geological Map of the World, France; *Corresponding authors, E-mail: c.francois.geology@orange.fr, manupub.pubel- \\ lier@gmail.com \\ ${ }^{2}$ Laboratoire de Géologie, CNRS UMR 8538, École Normale Supérieure, PSL University, France \\ ${ }^{3}$ Université Côte d'Azur, IRD, CNRS, Observatoire de la Côte d'Azur, Géoazur, 06560 Valbonne, France \\ ${ }^{4}$ Universiti Teknologi Petronas, Malaysia \\ ${ }^{5}$ Potsdam University, Germany \\ ${ }^{6}$ Université Orléans, CNRS, BRGM, ISTO, UMR 7327, F-45071 Orléans, France \\ ${ }^{7}$ Geological Survey of Canada, 601 Booth Street, Ottawa, Ontario K1A 0E8, Canada \\ ${ }^{8} \mathrm{https}: / /$ ccgm.org/en/content/11-team
}

(Received: March 18, 2021; Revised accepted: August 29, 2021)

https://doi.org/10.18814/epiiugs/2021/021025

Orogens develop in convergent settings involving two or more continental and/or oceanic plates. They are traditionally defined as zones of crustal deformation associated with mountain building resulting from either accretion of a terrane and/or an arc, continent-continent collision or rift-inversion. However, this definition does not consider the genetic link between an oceanic domain and an intracontinental rift, even though extension associated with a scissor-shape opening can be demonstrated in many oceanfloored basins. Consequently, we propose a new concept of orogenic evolution based on the development of extensional margins subsequently subjected to crustal shortening. Thus orogens that develop as a result of the closure of wide basins, are distinguished from mountain belts developed above subduction zones or that result from continental collision and inverted intra-continental rifts. Our review of several key orogens identifies similarities and differences in geodynamic processes through geological time including prior to the onset of plate tectonics $c$ a. 2.5 $\mathrm{Ga}$. We propose that mapping based on comparative tectonics is a good way to constrain such an evolution, and that this can start with a global-scale map of past-to-modern orogens aimed at re-exploring mountain building concepts spatially and temporarily. This is the primary objective of IGCP 667 project "World Map of Orogens".

\section{Introduction}

Orogens form along (or in proximity to) lithospheric plate boundaries in convergent settings (i.e., subduction, collision) and often involve two or more neighboring continental and/or oceanic plates. On the other hand, intracontinental orogens develop in an intraplate setting. The evolution of an orogen is a complex geodynamic process punctuated by several tectonic events that can be viewed as the "orogenic cycle", and in which an "orogeny" sensu stricto is a fundamental step (Fig. 1; Wilson et al., 2019). Orogenic belts as physiographic entities may be defined as a combination of folding, faulting, regional metamorphism and igneous activity within contemporaneously uplifted terrains (Kearey, 1993), with the orogenic components resulting from either continentcontinent collision or continent-ocean convergence (including continent-island arc accretion and ophiolite obduction) leading to crustal thickening. These two tectonic settings control the final orogenic architecture through geological processes both at depth and at the surface, including for example: the inversion of a passive margin, the emplacement of tectonic nappes, strike-slip faulting, the accretion of volcanic arcs, crustal magmatism, suture zone deformation and regional metamorphism (van der Pluijm and Marshak, 2004). Nevertheless, it remains key to differentiate accretionary orogens (Sengör and Okurogullari, 1991), where there is sequential amalgamation of terranes to a continental margin (e.g., the Cenozoic North American Cordillera or the Paleozoic Altaids Belt in Central Asia), from collisional orogens (Windley, 1992) where subduction leads to ocean-continent convergence (e.g., Andes of South America) and then continent-continent collision (e.g., Himalaya).

The definition of an orogen therefore becomes conceptually important and requires the identification the identification of the key diagnostic attributes of an orogeny. It also requires an accurate portrayal of such orogenic attributes on a geological or tectonic map including their location relative to craton boundaries and any older orogen. Such an approach emphasizes the evolutionary steps responsible for continental growth and underline any inherent reactivation process and/or history by documenting the superimposition of orogens through time and space. The resulting parsing of an orogenic belt into key attributes enables the construction of crustal cross-sections, along which 
overlapping or juxtaposed events can be considered. An important facet of IGCP 667 is thus the investigation of how basins and orogens interact with one another during continental growth, and how that interaction can be considered in terms of geological mapping and map compilations.

\section{Historical Overview}

Tectonic displacement from a geological mapping point-of-view was understood poorly until the end of the $19^{\text {th }}$ Century, although vertical movement intrinsic to mountain belt formation was already being considered (e.g., theory of mountain systems of Elie de Beaumont (1852); geosyncline theory of Hall and Dana (1873); eustatic variations of Suess (1893)). The first use of the terms "orographic" as applied to a mountain structure in a descriptive sense and "orogenic" in a genetic sense was made by Gressly (1840) and Thurmann (1854) in the Jura Mountains of France. A fundamental step in the establishment of tectonics as an individual science occurred with the geometric description of folds and faults responsible for stratigraphic inversions in the Appalachians of eastern North America by Rogers (1858). Lesley (cited in Chamberlin and Salisbury, 1906) further advanced our understanding of mountain belt structures by imagining the horizontal forces required to form large-scale folds, without however defining their specific nature. Elie de Beaumont's theory of mountain systems somehow evokes the equivalent of an orogeny in the mid- $19^{\text {th }}$ Century, but the collage of stratigraphic terranes was not sufficient to explain the formation of mountain belts. Crustal movement as a result of deformation was first theorized by the end of $19^{\text {th }}$ Century by Gilbert (1890) with the formulation of orogenic and epeirogenic uplift concepts, and in particular the relationship between fold-and-thrust mountain belts and lateralcompressional tectonics. However, Gilbert (1890) attached no specific time connotation to an orogeny. The concept of orogeny as "the process of mountain-building" was first developed by Upham (1894) who defined orogeny as "denoting the process of formation of mountains ranges by folds, faults, upthrusts and overthrusts, affecting comparatively narrow belts and lifting them in great ridges". Later, Haug (1907) distinguished four major orogenies: Huronian (end of Precambrian), Caledonian (Early Paleozoic), Hercynian (Late Paleozoic) and Alpine (Cretaceous). Stille (1920) reconsidered orogenesis as an episodic change in the rock deformation fabric, thus equating the term to both an event and a tectonic process. The definition of orogeny proposed by Stille (1940) involved the pervasive deformation of preexisting rock fabrics, limited in space and time and hence implying a spatiotemporal event, was widely accepted.

Major orogens are commonly generated by continental collision, but these can be superimposed through time and space thus potentially masking key information on the fundamental nature of the shortening processes involved. The understanding and classification of such processes therefore becomes crucial and includes documenting the reactivation of older tectonic features during mountain building, as well as in any subsequent ocean opening. It therefore becomes important to revisit the concept of orogeny and to also identify potential continental growth through mantle extraction processes through time and space.

The present overview of the world's orogens is part of the ongoing IGCP 667 Project "World Map of Orogens", in which the main driver is to design a map at scale 1:35,000,000 documenting the distribution of ancient to modern orogens throughout Earth history. The compilation of a "World Map of Orogens" necessarily requires a careful consideration of both the various types of global-scale compressional tectonic regimes and the best means of portraying the associated tectonic elements or attributes on such a map. When documenting preplate tectonic terrains ( $c a .>2.5 \mathrm{Ga}$ ), Early Earth crustal deformation processes and features need to be considered. In order to document orogens of all ages, we propose a slight simplification of the main tectonic attributes of any given orogeny principally due to the potential for increasing paucity of data in deep time. We conclude by presenting a number of orogens, from the Paleoproterozoic to the present, with a legend that includes the key elements of a "typical" orogen.

\section{A Four-fold Geodynamic Classification of Orogens}

Recent evolutionary models of continental margins and basins (d'Acremont et al., 2006; Fournier et al., 2010; Pubellier et al., 2016; Bulois et al., 2018), as well as comparisons between modern and ancient orogenic systems (e.g., Weller and St-Onge, 2017; Brown and Johnson, 2018; Palin et al., 2020), emphasize the notions of margin evolution, basin development, rift propagation and basement reactivation. In the documentation of most orogenic systems, a space-time continuum of deformation affecting the various geological elements of a mountain belt is reported. This continuity of tectonic events can be directly linked to the Wilson Cycle (Fig. 1). Given the current understanding that geological processes are intimately linked to orogenic evolution, it seems timely to propose a different geodynamic classification of orogens in order to emphasize the overall tectonic processes occurring during lithospheric shortening.

Four main types of convergent orogenic systems (aka "stages") can be identified within the present-day geodynamical settings encountered on Earth (Fig. 2): (i) ocean-continent convergence accommodated by subduction, (ii) accretion/collision/obduction of crustal elements derived from subduction (island arc and/or back-arc basin), or occurring as a microcontinent, ribbon continent, oceanic plateau or ridge, (iii) continental collision, often following subduction \pm accretion \pm obduction and (iv) shortening of an inverted intracontinental sedimentary basin and continental crustal materials. Each of these types in turn may only represent one step in the development of an orogen in time and space, thus a transition between each stage can and should be considered. Indeed most of these orogens will result in the generation of topography, particularly continental collision, which can be followed by orogenic collapse along large low angle normal faults, which are generally located at the frontier between zones of strongly varying rheologies. This post orogenic stage aspect is not developed in the synthesis.

Type I (Fig. 2a) involves ocean-continent convergence and leads to the formation of a mountain belt on the overriding upper plate, as a result of igneous material sourced from the underlying subduction zone. Compression may happen during oceanic subduction when there is a change in subduction attributes such as the dip or the relative velocity of the subducting slab, the obliquity of the convergence, or the amount of sedimentary material deposited in the trench, underplated or subducted with the downgoing plate. This results in a non- 


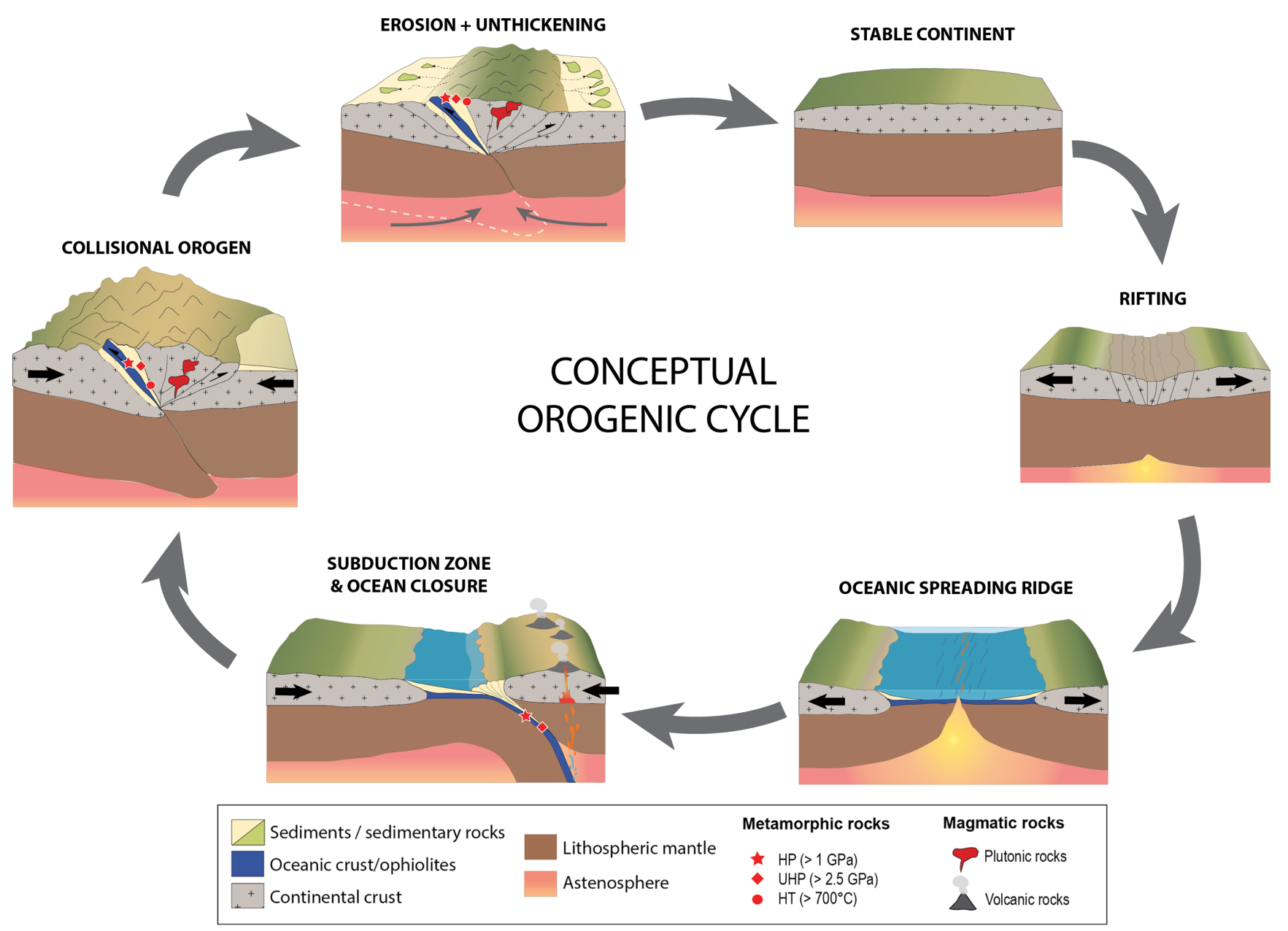

Figure 1. Cyclic view of the different stages of a theoretical orogenic cycle as an extension-compression continuum (Wilson Cycle).

collisional system typical of Andean-type cordilleras (South America, Eastern Australia, and Antarctica; Ramos, 1988; 1999). The Type I orogen is often considered as a precursor to continental collision ( $\mathrm{cf}$ Type III), so that the resulting mountain range built on the upper plate can be referred to as the "early-orogenic zone".

Type II (Fig. 2b) involves micro- or ribbon-continents and slivers of a continental margin rifted during the opening of back-arc basins. The slivers may also include oceanic plateaus (e.g., Ontong-Java in the Solomon Islands), exotic island arc terranes (e.g., North American Cordillera) or continental accreted terranes (e.g., Cascadia). The convergent process is often known as terrane docking or accretion and it results in a tectonic collage of pericratonic and suspect terranes (Coney et al., 1980; Howell, 1989). The accretion of pericratonic, suspect, or exotic terranes represents a milestone in the history of an oceanic basin. The orogen forms when a crustal domain is rifted away from a continental margin and eventually reaches an active continental margin. As subduction of the now-accreted crustal domain is not possible, subduction jumps to the opposite side of the docked terrane (e.g., Anatolia, Iran; Barrier and Vrielynck, 2008, or SE Asia; Pubellier and Meresse, 2013). Where observations are more complete (e.g., Cenozoic convergent settings), the docked crustal domains are often back-arc basins floored by continental basement, or island arcs. This stage may therefore be considered as a prelude to the eventual formation of a continental collisional belt (Type III).
Type III (Fig. 2c) is characterized by the collision of two or more continental landmasses. Continental collision, sometimes referred to as "terminal collision" in the literature (e.g., Najman et al., 2017; Abu Sharib et al., 2019), is characterized by a pre-collisional history that can involve a lengthy period of subduction and terrane accretion (cf., Types I and II). Because of the crustal thickness of the subducting lithosphere and its positive buoyancy, most of the incoming material cannot be subducted, or remain subducted, leading to crustal shortening, accommodated by low-angle syn-metamorphic ductile shearing and orogeny. Therefore, a continent-continent collision follows the complete closure of an oceanic basin (e.g., Himalaya, European Alps) and the closure of the arc and/or back-arc system in the upper plate.

Type IV (Fig. 2d) is an intra-continental orogen formed during the inversion of a rift system that originated from pre-orogenic rifting that never led to the formation of oceanic crust. The Atlas Mountains in NW Africa are a classic example of this type of orogen, in which only the upper structural levels and the metamorphic rocks they contain are exposed (e.g., Mattauer et al., 1977; Frizon de Lamotte et al., 2000).

Another example from the South China Block comprises a Silurian intracontinental orogen, in which deep seated metamorphic zones are exposed. The Early Paleozoic Orogen (EPO) of South China, has long been recognized due to a Devonian unconformity (Grabau, 1924). This pre-Devonian belt resulted from the closure of a Neoproterozoic to Ordovician rift within continental crust and without involving oceanic 


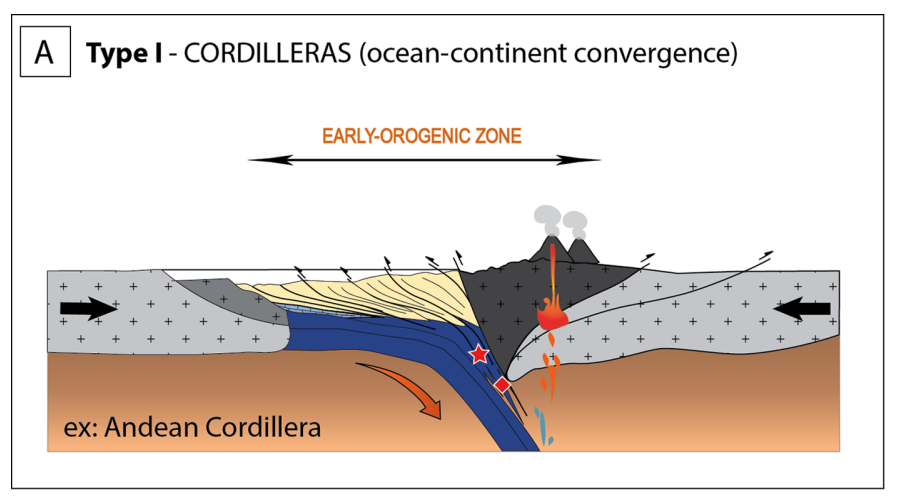

B Type II - ACCRETED TERRANES (oceanic plateau, arc, ribbon continent)
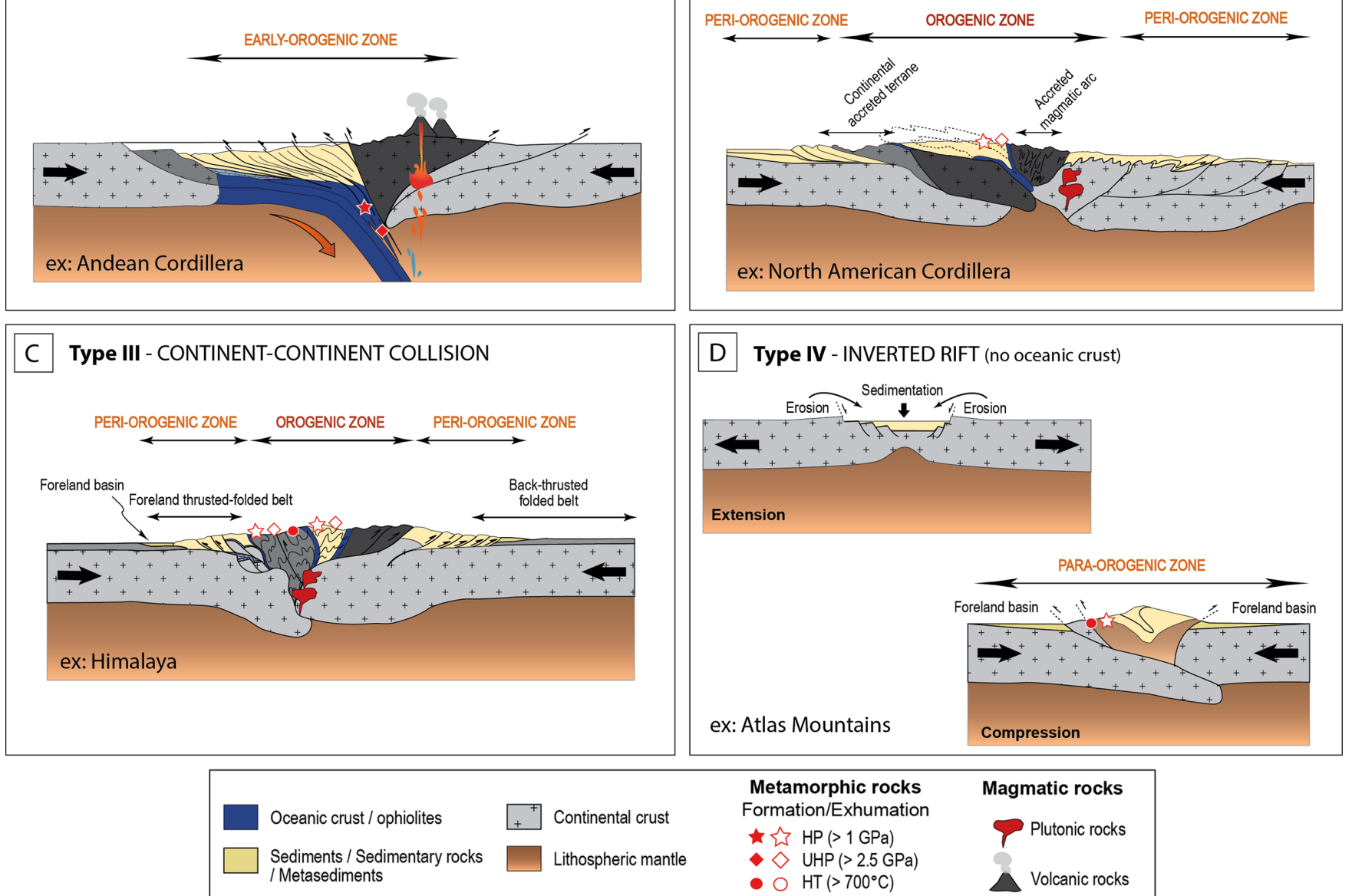

$\begin{array}{ll}\text { Metamorphic rocks } & \text { Magmatic rocks } \\ \text { Formation/Exhumation } & \text { Plutonic rocks } \\ & \curvearrowleft \mathrm{HP}(>1 \mathrm{GPa}) \\ \diamond \mathrm{UHP}(>2.5 \mathrm{GPa}) & \text { Volcanic rocks }\end{array}$

Figure 2. The different types of orogens. (a) Subduction type, (b) accreted terranes type, (c) continental collision type (d) intracontinental type. Figures modified from Lagabrielle and Bodinier (2008) and Robert and Bousquet (2018).

crust (e.g., Yao et al., 2014). The rift closure was accommodated by a north-directed continental subduction as shown by south-verging folds and thrusts, and ductile kinematics in the southern part of the belt (Faure et al., 2008; Charvet et al., 2010; Li et al., 2010; Wang et al., 2013; Xin et al., 2020 and enclosed references). The inner zone of this orogen consists of mid temperature and mid pressure biotite-garnetstaurolite-kyanite metapelites and garnet amphibolites that document P-T conditions at 1.0-1.2 GPa and $500-600^{\circ} \mathrm{C}$ (Zhao and Cawood, 1999). The driving force for the intracontinental orogen is interpreted as being the far-field effect of the Ordovician collisional orogeny recognized in central Vietnam, responsible for the welding of the VietCambodia block and the Viet-Lao (or North Vietnam-South China) blocks (Faure et al., 2018).

Intracontinental orogens may also result from highly oblique continental collisions (e.g., Southern Alps of New Zealand; Beaumont et al., 1996), where transpressionnal components can also play important roles. In spite of a unique initial pre-orogenic setting, the intracontinental orogens exhibit structural, metamorphic, plutonic and sedimentary features similar to those of type III orogens (cf., Table 1).

As a broad generalization, a Type I orogen can often represent an early stage of a Type II or Type III orogen. In this overview, we have defined an "early orogenic zone" (Table 1), which can be compared and contrasted to the three other (generally subsequent) orogenic stages and zones: peri-orogenic/orogenic zones (types II and III) and paraorogenic zones (Type IV).

The "orogenic zones" in types II and III are associated with the presence of ophiolites, (Ultra) High Pressure ((U)HP) and (Ultra) High Temperature ((U)HT) metamorphic rocks and plutonism (granites). The "peri-orogenic zones" correspond to areas of more moderate deformation, lower grade metamorphism, moderate topography, the presence of molassic foreland basins as well as fold-and-thrust belts developed above shallow detachment levels. The "para-orogenic zone" (Table 1), is associated with Type IV orogens and is characterized by moderate deformation along inverted rifted features, occasionally low-grade metamorphism and the exhumation of mantellic material without the presence of oceanic crust as a result of the shortening of former propagator tips.

\section{The Geometry of Basins and Orogenic Impli- cations}

The crustal structure of a rifted basin is important since it will impact any subsequent tectonic inversion. The precise end of the rift- 
Table 1. Relevant geodynamic components and attributes by orogenic zones

\begin{tabular}{|c|c|c|c|c|c|c|c|}
\hline $\begin{array}{l}\text { Types of } \\
\text { orogens }\end{array}$ & $\begin{array}{l}\text { Orogenic } \\
\text { zones }\end{array}$ & $\begin{array}{l}\text { Oceanic } \\
\text { closure }\end{array}$ & Magmatism & Metamorphism & $\begin{array}{l}\text { Fold and } \\
\text { Thrust Belt }\end{array}$ & $\begin{array}{l}\text { Pre- to syn-orogenic } \\
\text { sediment deposit }\end{array}$ & $\begin{array}{c}\text { Late- to post } \\
\text { orogenic sediment } \\
\text { deposit }\end{array}$ \\
\hline $\begin{array}{l}\text { Cordilleras } \\
\text { (Type I) }\end{array}$ & $\begin{array}{l}\text { EARLY-ORO- } \\
\text { GENIC }\end{array}$ & in progress & $\begin{array}{l}\text { Volcanic \& plu- } \\
\text { tonic rocks (Primary } \\
\text { melts, dominantly } \\
\text { calco-alcaline) }\end{array}$ & $\begin{array}{c}\text { in lower part: HP/ } \\
\text { LT }\end{array}$ & Accretionay prism & $\begin{array}{l}\text { Formation of a retro- } \\
\text { arc foreland basin, } \\
\text { Thick sedimentary } \\
\text { sequence Flysch- } \\
\text { Accretionary wedge }\end{array}$ & $\begin{array}{l}\text { Absent but sedi- } \\
\text { ments deposited in } \\
\text { the forearc basin } \\
\text { may unconformably } \\
\text { cover the Fold and } \\
\text { Thrust Belt (FTB) }\end{array}$ \\
\hline \multirow[b]{2}{*}{$\begin{array}{l}\text { Accreted } \\
\text { terranes } \\
\text { (Type II) }\end{array}$} & OROGENIC & $\begin{array}{c}\text { YES } \\
\text { (Multiple) } \\
\text { ophiolites }\end{array}$ & $\begin{array}{l}\text { Syn-collisional } \\
\text { (Migmatites and } \\
\text { aluminous granites) }\end{array}$ & (U)HP (U)HT & - & - & - \\
\hline & $\begin{array}{l}\text { PERI-ORO- } \\
\text { GENIC }\end{array}$ & - & - & - & $\begin{array}{l}\text { FTBs form where } \\
\text { passive continen- } \\
\text { tal margins } \\
\text { collide with a sub- } \\
\text { duction zone }\end{array}$ & 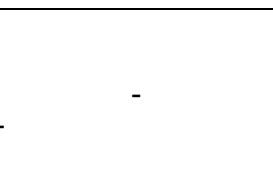 & Molassic basin \\
\hline \multirow{2}{*}{$\begin{array}{l}\text { Continent- } \\
\text { Continent } \\
\text { (Type III) }\end{array}$} & OROGENIC & $\begin{array}{l}\text { YES ophio- } \\
\text { lites or } \\
\text { ophiolitic } \\
\text { mélange }\end{array}$ & $\begin{array}{c}\text { Syn-collisional } \\
\text { (Migmatites and } \\
\text { (per)-aluminous } \\
\text { granites) }\end{array}$ & $\begin{array}{c}\text { HP/UHP } \\
\text { (prograde) during } \\
\text { continental } \\
\text { subduction and } \\
\text { MP-LP/(U)HT } \\
\text { (retrograde) } \\
\text { coeval with crustal } \\
\text { melting }\end{array}$ & - & $\begin{array}{l}\text { Passive continental } \\
\text { margin deposits }\end{array}$ & - \\
\hline & $\begin{array}{l}\text { PERI-ORO- } \\
\text { GENIC }\end{array}$ & - & - & - & $\begin{array}{l}\text { Bilateral foreland/ } \\
\text { hinterland FTB }\end{array}$ & $\begin{array}{l}\text { Passive continental } \\
\text { margin deposits, } \\
\text { (volcanic)-sedimen- } \\
\text { tatry terrigenous } \\
\text { rocks turbiditic } \\
\text { deposts }\end{array}$ & $\begin{array}{c}\text { Thick molassic } \\
\text { deposits in foreland } \\
\text { and hinterland basins. } \\
\text { Intramontane basins }\end{array}$ \\
\hline $\begin{array}{l}\text { Inverted } \\
\text { rift } \\
\text { (Type IV) }\end{array}$ & $\begin{array}{l}\text { INTRAPLATE } \\
\text { / PARA-ORO- } \\
\text { GENIC }\end{array}$ & $\begin{array}{l}\text { NO real } \\
\text { oceanic } \\
\text { closure }\end{array}$ & $\begin{array}{l}\text { No magmatic arc } \\
\text { Migmatites and } \\
\text { (per)aluminous } \\
\text { granites }\end{array}$ & $\begin{array}{l}\text { Prograde and ret- } \\
\text { rograde } \\
\text { metamorphism }\end{array}$ & FTB & $\begin{array}{l}\text { Passive continental } \\
\text { margin deposits, } \\
\text { (volcanic)-sedimen- } \\
\text { tatry terrigenous } \\
\text { rocks }\end{array}$ & Molassic deposit \\
\hline
\end{tabular}

Abbreviations: FTB: Fold and Thrust Belt; HP: High Pressure; UHP: Ultra High Pressure; MP: Mid Pressure; LP: Low Pressure; UHT: Ultra High Temperature; LT: Low Temperature.

ing (breakup) is contemporaneous with the first sedimentary units deposited on oceanic crust and can sometimes be confirmed with the presence of clear oceanic magnetic anomalies. The opening is rarely orthogonal, implying an along-strike migration of breakup with time (Fig. 3). The newly formed oceanic crust is therefore wider at one end and narrower on the opposite end of the newly formed basin (Fig. 3a). It might even be connected to a continental rift inland, which is devoid of oceanic crust. The resulting V-shape geometry yields strong implications on the style of any subsequent shortening and timing of eventual basin closure.

\section{Non-orthogonal Opening of Basins, and Propagation of Rift Systems}

Most of the well-documented marginal basins have a scissor-shape geometry resulting from the propagation of a rift toward locked zones (Courtillot, 1982). Notable examples include the Woodlark Basin (Weissel and Watts, 1979; Taylor et al., 1999), the Gulf of Aden (Courtillot, 1982; d'Acremont et al., 2006; Fournier et al., 2010) and the South China Sea (Fig. 3; Briais et al., 1993, Franke et al., 2014; Pubellier et al., 2016). In continental rift systems, such as the North Atlantic, a similar along-axis propagation of the deformation is also documented based on paleogeographic reconstructions (e.g., Ziegler, 1990) but the absence of clear oceanic crust in some cases (e.g., Gakkel ridge) remains problematic to fully understanding how deformation propagates spatially and temporarily. In general, the propagation of rifts is due to either a lateral variation in the timing of the initial breakup due to local weaknesses of the continental crust, or to the proximity of the Euler rotation pole with the tip of V-shape rifted basin. The breakup point migrates with continued extension as long as the basin is opening (e.g., Martin, 1984; Taylor et al., 1999; Péron-Pinvidic and Manatschal, 2010; Fletcher et al., 2013), so that the breakup unconformity is diachronous alongstrike, with break-up ages decreasing in the direction of propagation (Gaina et al., 1999; Franke et al., 2014; Ding and Li, 2016). The integration of field and seismic studies documents that rift propagation slows down or stops when the rift tip abuts transversal structures of orogenic origin (e.g., Bulois et al., 2018). Numerical models have shown that tectonic loading in the propagation direction is crucial for slowing down or halting continental rifting and allowing the development of a wide triangular zone of stretching and thinning of the continental crust (Le Pourhiet et al., 2018).

One of the best-documented rift propagator is the South China Sea Basin (Taylor and Hayes, 1983), where all these characteristics are documented. The rift migration (Franke et al., 2014) produced a large ocean-floored basin in the NE (Eastern Sub-basin) and a narrow ocean floor in the central part (SW sub-basin) with the tip correspond- 


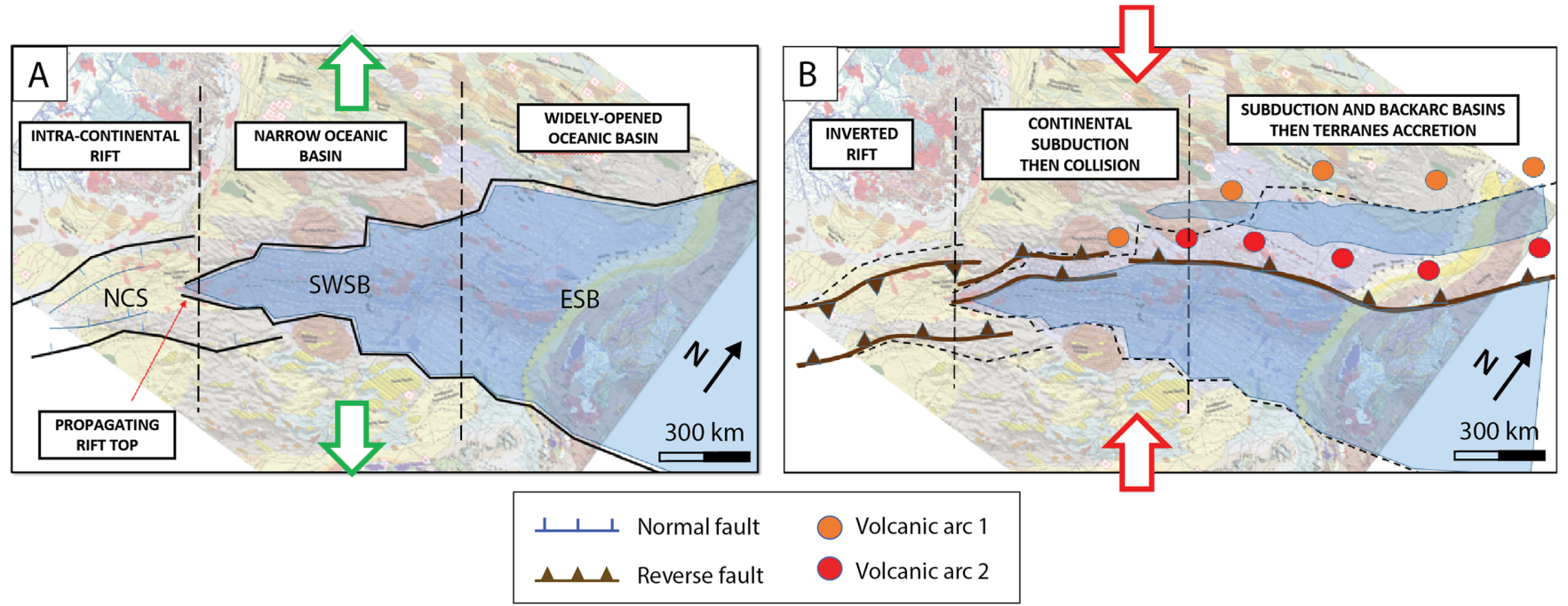

Figure 3. Theoretical "scissor shape". (a) Active opening setting and (b) projected setting during shortening. The background is an example modified from the Structural Map of the South China Sea (Pubellier et al., 2017; (C) CCGM-CGMW 2017; doi:10.14682/2017STRUCTUSCS); NCS; Nam Con Son Basin, SWSB; SW sub-basin, ESB; Eastern Sub-basin. Figure (b) is a speculative scenario for future basin closure.

ing to a continental rift south of Vietnam-the Nam Con Son Basin (Fig. 3a; Li et al., 2014; Sibuet et al., 2016). The subdivisions of the basin reflect interaction with the surrounding continental and oceanic crust, for example in the form of depocenter locations. The opening of the South China Sea is concomitant and related to the closure of the neighbouring basin by slab pull (Pubellier and Meresse, 2013). Thus the opening begins at a place where the pull effect was strong and migrated globally from NE to SW, implying a constant relocation of tectonic stresses within the portion of the continental crust affected by the propagation. Far from being anecdotic, this would seem to be the case in most basins, though admittedly it is more difficult to detect in large oceans. In large oceanic basins bounded by well-defined continental margins (e.g., Tasman Sea, Atlantic Ocean; Guiraud and Maurin, 1992; Seton et al., 2012a, b), similar opening mechanisms might be considered, recognizing that these may be masked by subsequent changes in basin boundary conditions.

\section{Implications on the Geodynamic Classification of Oro- gens}

In oceanic rift systems, the oceanic crust is predominantly associated with exhumed mantle outboard of the continent-ocean transition (COT), and the divergent system transitions laterally to a younger continental extensional domain toward the propagator tip (Fig. 3a, e.g., Benes et al., 1994; Taylor et al., 1995, 1999; Goodliffe et al., 1999; Martinez et al., 2001; Minshull, 2009; Li et al., 2014). The type of geological setting where subduction is the driving mechanism for extension in neighboring crust promotes a scissor-like opening, with an oceanic basin forming following the propagator tip and a continental rift or aulacogen forming before the arrival of the propagator tip. This transition occurs in several steps controlled by transfer faults near the COT and larger transform faults in the oceanic domain. This is particularly well documented in the recent rift propagators mentioned above. It is also envisaged for the Proto-Tethys Ocean in the Early Paleozoic (Scotese, 2016), as well as for the Paleo-Tethys in the Late Paleozoic (Stampfli and Borel, 2002). In the case of the Neo-Tethys Ocean, it appears that the continental blocks that rifted away from the main continent were larger in the East where the ocean was wider (Scotese, 1991; Stampfli and Borel, 2002; Pourteau et al., 2010), resulting in wider Phanerozoic Tethysides (Sengör and Natal'in, 1996).

The above extensional mechanisms imply along-strike time-variation of opening, which is reflected in the distance between the opposite conjugated margins. Such a V-Shape geometry is documented in the South China Sea and in the Woodlark Basin, and it is also applicable to the large but simple example of the Atlantic Ocean, which opened in a northward direction from the Early Cretaceous to the Eocene, ending as a rift at the northern end of the Gakkel Ridge in the Arctic Ocean.

In any plate convergence system, when the basin margins close, a reverse migration of the locus of closure will occur, from an early collision in the nascent rift system to a later subduction-accretion stage followed by continental collision toward the open end of the V (Fig. $3 b)$. In other words the timing of collision should be diachronous along strike, with resulting differences in the time of deformation of the accretionary wedges, as well as the formation of the post-orogenic molasse basins. Such a scenario also implies that the material engulfed in the collision zone evolves laterally from an accretionary wedge to a continental wedge, as is documented from the Eastern Sunda wedge to the Burma-Bangladesh fold-and-thrust belt, or from the Muertos wedge to the Haïti fold-and-thrust Belt in Hispaniola. Intra-oceanic deformation prior to collision and ophiolite thrusting would take place in that part of the oceanic realm that was formerly wide, while no oceanic or ultramafic material would be found in the intra-continental rift region. This type of along-strike variation is observed in the western Pyrenees where the oceanic-floored V-shaped Bay of Biscay is expressed inland as shortened packages of serpentinized mantle within the orogenic belt (Lagabrielle and Bodinier, 2008; Jammes et al., 2009; Tugend et al., 2014). 


\section{Temporal Evolution of Orogens}

\section{Early Earth Geodynamic Processes (before 2.5 Ga)}

Today, the global tectonic regime is dominated by plate tectonics or mobile-lid tectonics including deep and cold subduction and/or collision. However, the early Earth $(>2.5 \mathrm{Ga}$ ) was subject to a very different, higher mantle heat flux and a thermal regime characterized by the formation of unique lithomagmatic assemblages including the emplacement of tonalite-trondjhemite-granodiorite (TTG) suites in the early continental lithosphere and the formation of granite-greenstone terrains (e.g., Arndt and Nisbet, 1982; Abbott and Hoffman, 1984; Taylor and McLennan, 1985; Abbott et al., 1994; Jaupart et al., 2007; Coltice et al., 2009; Gapais et al., 2009; Bédard, 2018; Tang et al., 2019; Hernández-Montenegro et al., 2021). Accordingly, the early Earth was dominated by different geodynamical processes (Fig. 4), including flat or low angle subduction (mobile-lid tectonics; Smithies et al., 2003) and sagduction (stagnant-lid tectonics; MacGregor, 1951). Sagduction is thought to have been driven by partial convective overturn due to the density contrast between dense (ultra) mafic cover (greenstone belts) and the more felsic crustal basement (TTG), coupled with partial melting in the lower crust (Collins et al., 1998; Van Kranendonk et al., 2004; Thébaud and Rey, 2013; François et al., 2014; Bédard, 2018). This resulted in the typical Archean dome-and-keel structures with TTG terrains forming ovoid domes surrounded by narrow and strongly pinched greenstone belts. Such a configuration is not suggestive of large tangential movements of plates, and the complete absence of ultra-high pressure (UHP) metamorphic assemblages also suggest a completely different geodynamic or thermal regime (Brown and Johnson, 2018). In addition, the very local evidence of Archean ( \pm flat) subduction is rare and controversial (Volodichev et al., 2004; Moyen et al., 2006). It would seem that the thermal (i.e., a higher mantle heat flux) and the rheological conditions prevalent during the Archean Eon probably made modern steep subduction (burial of a lithospheric panel at great depth) impossible.
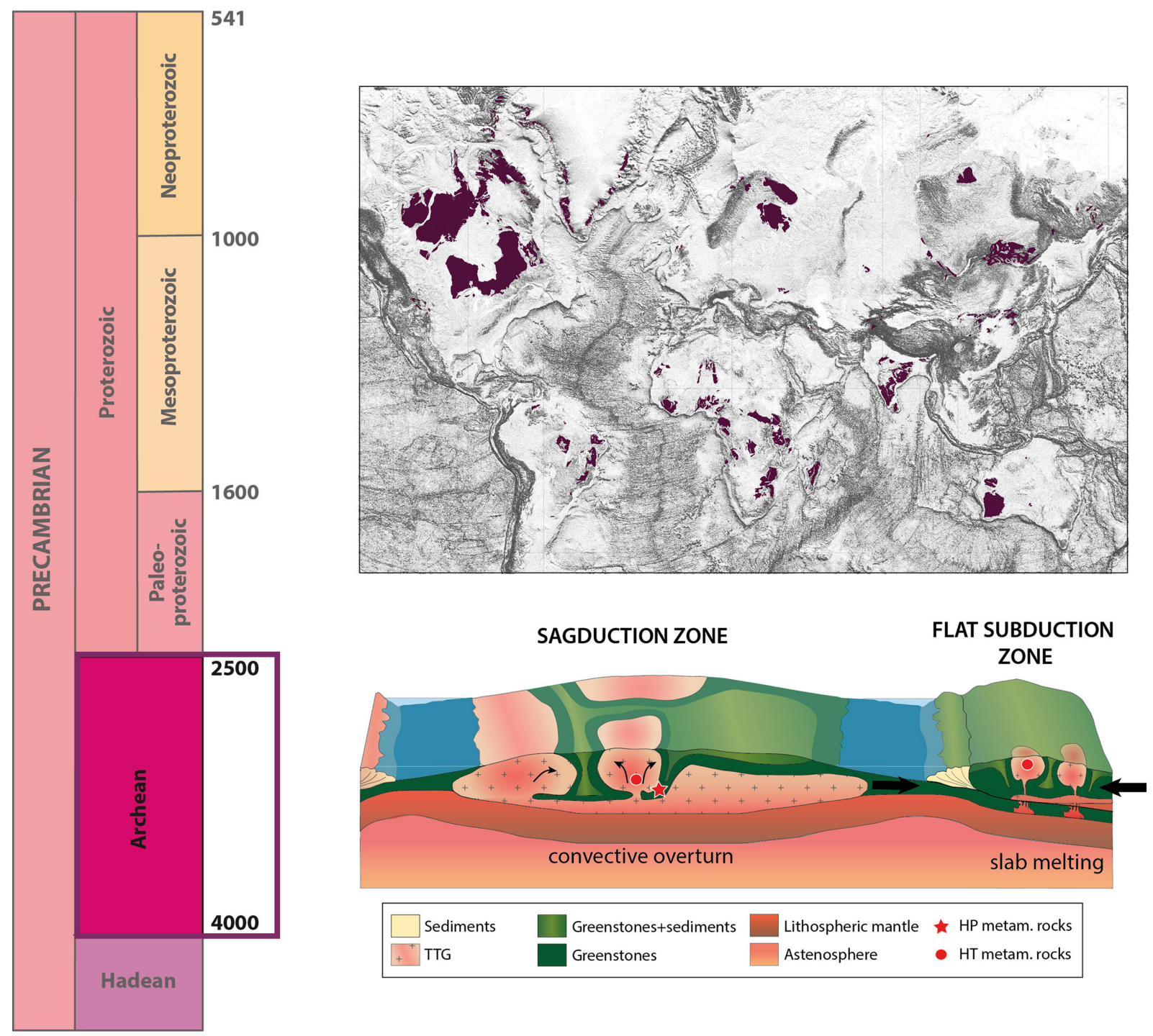

Figure 4. Extent of Archean crust on the World Map and representative Archean dome and keel structures formed by geodynamical processes that ended at about $2.5 \mathrm{Ga}$ : flat subduction and sagduction of dense greenstone lithologies into lighter felsic crystalline basement. The higher mantle heat flux is envisioned as leading to the partial melting of the lower crust (flat subduction) and the convective overturn of the Archean crust (sagduction). 
The Archean metamorphic rock record and implied pressure-temperature (PT) conditions (apparent geothermal gradient) can be used to discriminate geodynamic processes in the early Earth, and more particularly to infer whether or not deep and cold subduction similar to that of modern plate tectonics was operational (Brown, 2008; Brown and Johnson, 2018). The oldest evidences of high pressure (HP) rocks (> $15 \mathrm{kbar}$ ) are bracketed between 2.2 and $1.8 \mathrm{Ga}$ (e.g., Möller et al., 1995; Baldwin et al., 2004; Collins et al., 2004; Volodichev et al., 2004; Boniface et al., 2012; Weller and St-Onge, 2017; François et al., 2018; Loose and Schenk, 2018; Xu et al., 2018). Consequently, these authors suggest a beginning for modern-style plate tectonics and therefore orogens (as per the types presented above) at or following 2.5 Ga (St-Onge et al., 2006; François et al., 2018; Brown and Johnson, 2020). Others authors propose a beginning for plate tectonics as early as 3.2 to $4.0 \mathrm{Ga}$ (Nutman et al., 2002; Cawood et al., 2006; Shirey et al., 2008; Richardson and Shirey, 2011; Windley et al., 2020), however this is mainly based on geochemical data. It is for this reason that we decided to document orogens and their attributes post $2.5 \mathrm{Ga}$ and to represent old geodynamic features (i.e., Archean dome-and-keel structures) on the craton map (Fig. 4).

\section{“Modern” Orogens (after 2.5 Ga)}

The convergent margin geodynamic processes that developed after the end of the Archean, whilst continuing to undergo progressive change as a result of the continued secular cooling of the Earth, have nevertheless remained remarkably consistent, and therefore identifiable. We choose to illustrate this aspect with examples from the Trans-Hudson, the Caledonian, the Variscan-Uralian and the Alpine systems, which show somewhat finer resolution with time. In all these examples, we restrict the definition of an "orogen" to spatial areas affected by tectonic events within and on the borders of former oceans.

\section{Trans-Hudson Orogeny and Closure of the Manikewan Ocean}

The middle to late Paleoproterozoic, and specifically the aptly named Orosirian Period (2050-1800 Ma), recorded the assembly of Earth's first genuine supercontinent variably referred to as either Nuna, Columbia, or Hudsonland (Piper, 1976; Hoffman, 1988; Park, 1995; Meert, 2002, 2012; Pesonen et al., 2003). The primary evidence for Nuna is based on paleomagnetic data and on comparative geology, and observed through alignment and broad synchronicity of geological features including mafic dyke swarms, rift and continental-margin supracrustal sequences, suture zones, oceanic and continental magmatic arcs, obducted ophiolites, thrust and fold belts, localities of low thermal gradient metamorphism, and in particular 2.00-1.74 Ga orogenic belts on a majority of the continents (Fig. 5; Zhao et al., 2002, 2011; Evans and Mitchell, 2011; Evans et al., 2016; Meert and Santosh, 2017; de Oliveira Chaves and Porcher, 2020; Wan et al., 2020).

The largest of the Nuna-affiliated orogenic belts is the ca. 1.921.74 Ga Trans-Hudson orogen (Hoffman, 1988; Lewry and Stauffer, 1990), which comprises locally superbly exposed erosional remnants of a collisional mountain belt that extended $\sim 4,600 \mathrm{~km}$ across North America into northeastern Arctic Canada (Fig. 5). In Greenland, the continuation of the Trans-Hudson orogen is the well-studied, but largely ice-covered, Nagssugtoqidian orogen (Fig. 5; van Gool et al., 2002; Nutman et al., 2008a; St-Onge et al., 2009; Garde and Hollis, 2010; Kolb, 2014; and references therein). Further to the east, the Trans-Hudson orogen is manifest as the Lapland-Kola orogen in Baltica (Fig. 5; Daly et al., 2006; Korja et al., 2006; Petrov et al., 2018; Lahtinen and Huhma, 2019). In Canada, numerous studies of the Trans-Hudson orogen have shown that it formed during progressive closure of the Manikewan Ocean and accretion of intervening suspect terranes, culminating with the collision of the lowerplate Archean Superior craton with an upper-plate collage of Archean and Paleoproterozoic crustal blocks (collectively known as the Churchill plate) at ca. $1.82 \mathrm{Ga}$ (St-Onge et al., 2006, 2007, 2009, 2020; Corrigan et al., 2009; Corrigan, 2012; Weller and St-Onge, 2017; Weller et al., 2020; and references therein). Several parallels have been drawn between the Trans-Hudson orogen and the archetypical HimalayaTibet orogen of central Asia as both orogens are of a similar scale and exhibit similar patterns of magmatism and metamorphism with respect to the timing of collision (St-Onge et al., 2006; Eaton and Darbyshire, 2010; Thompson et al., 2010; Bastow et al., 2011; Corrigan, 2012; Weller and St-Onge, 2017).

Signature tectonic features that characterize Trans-Hudson orogen include mounting evidence for continental subduction during diachronous plate convergence as documented by high-to ultrahighpressure/low-temperature mineral assemblage localities, and closure of intervening oceanic domains as witnessed by obducted ophiolitic suites (Scott et al., 1992; Peltonen and Kontinen, 2004; Garde and Hollis, 2010). Within the Trans-Hudson orogen of Laurentia and Baltica well-researched Paleoproterozoic eclogite localities include: the $1.83 \mathrm{Ga}$ Kovik eclogite (Weller and St-Onge, 2017), the 1.87 Ga Kuummiut eclogite (Nutman et al., 2008b; Müller et al., 2018) of SE Greenland, and the 1.9 Ga Belomorian eclogite (Yu et al., 2017) of western Russia (Fig. 5). Taken as a set, the Trans-Hudsonian eclogites record a clear east-to-west diachronous trend in the age of continental subduction and orogenesis, and by inference, Manikewan Ocean closure.

\section{Caledonian Orogeny and Closure of the Iapetus Ocean}

On the northern British Isles, during the Early-Middle Ordovician (ca. 470-460 Ma), a volcanic island arc (the Midland Valley arc terrane) that had formed along the margins of the Iapetus Ocean, collided with Laurentia (Fig. 6). This marked the onset of the Grampian phase of the Caledonian orogeny (Strachan and Woodcock, 2021). Sedimentary and igneous rocks trapped between the colliding landmasses were intensely folded and faulted and subject to varying degrees of regional metamorphism (Smooth, 2012).

The subsequent (or continuing) Scandian phase of the Caledonian orogeny, which occurred from the Ordovician to the Middle Silurian (450 - $430 \mathrm{Ma}$ ), resulted in full closure of the Iapetus Ocean and amalgamation of Laurentia, Baltica and Avalonia to form Laurussia (Fig. 6). Early phases of deformation and/or metamorphism are recognized in the Scandinavian Caledonides and resulted from eastern Avalonia moving independently towards Baltica during the Ordovician. This motion was accommodated by the subduction of the southeastern Iapetus Ocean (so called Tornquist Sea) beneath Avalonia. The continental collision between Avalonia and Baltica 

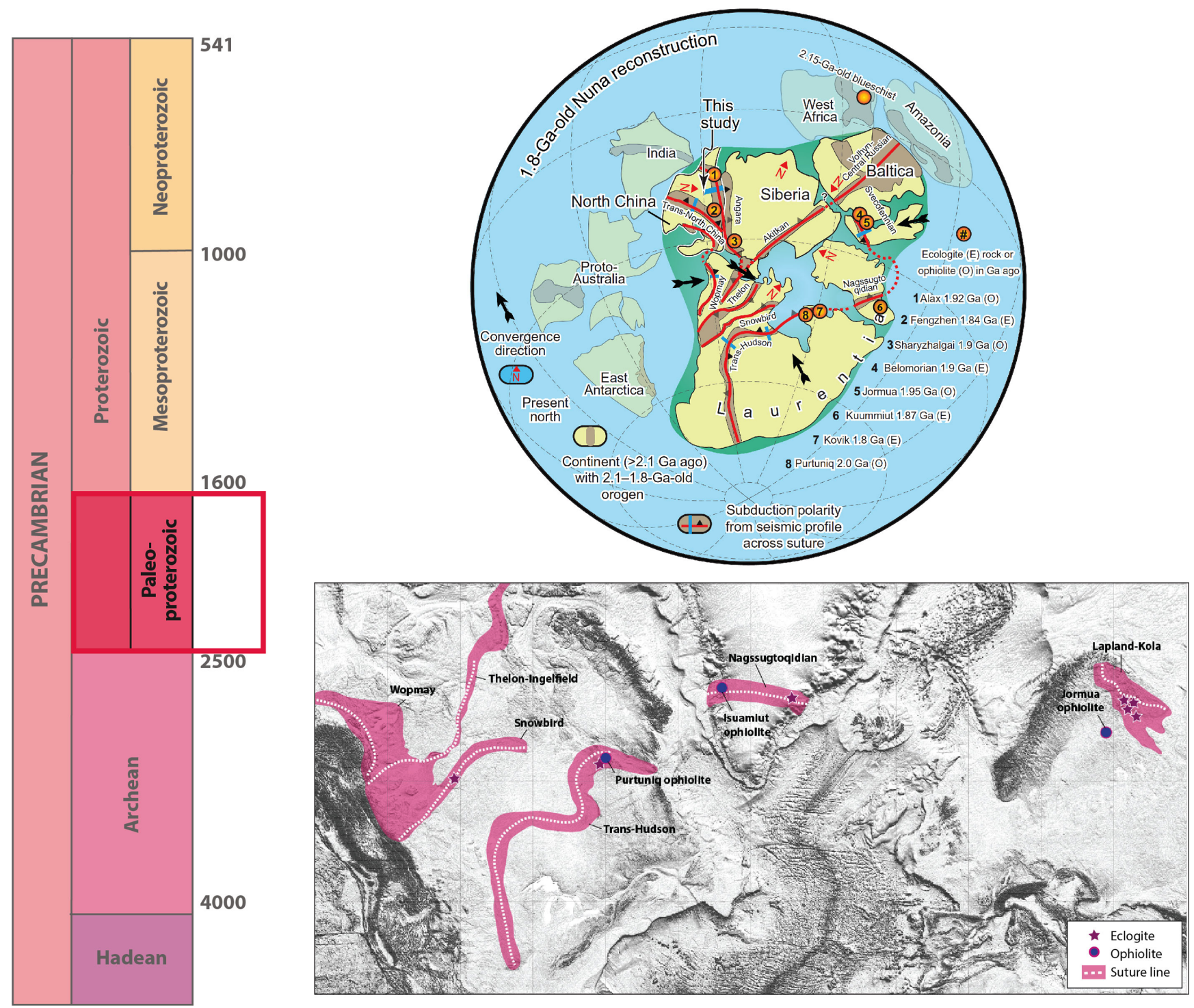

Figure 5. Present extent of some of the Paleoproterozoic orogens (may include reworked Archean crust) in the North Atlantic realm on the World Map, and in the past as shown on a Nuna reconstruction 1.8 Ga ago (Evans and Mitchell, 2011), including the position of North China (Wan et al., 2020). Convergence directions (black arrows) are inferred from subduction polarity (black triangles) indicated at seismic profiles (blue). Speculated continuation of seismically confirmed sutures (red). A 2.15-Ga-old blueschist immediately preceding the Orosirian period is shown (Ganne et al., 2012). Green region marks configuration of core continents assembled through two to three major sutures. Putative positions in the larger supercontinent Nuna are suggested for other less studied continents (slightly transparent). Seismic evidence is consistent with previous paleomagnetic and geological configurations in the green region under the paradigm of a modern, global subduction-driven plate tectonic network. From Wan et al. (2020). Location of eclogites and blueschist from: Kola-Lapland orogen, Belomorian Province, Russia (Volodichev et al., 2004; Skublov et al., 2011; Slabunov et al., 2011); Nagssugtoqidian orogen, South-East Greenland (Nutman et al., 2008b; Müller et al., 2018); Trans-Hudson orogen, North America (Weller and St-Onge, 2017); Snowbird Tectonic Zone, Canada (Snoeyenbos et al., 1995; Baldwin et al., 2003, 2004).

began in the Late Ordovician, about 450 Myr ago (Fig. 6). As a result, the Tornquist Sea was consumed and the resulting suture became the Tornquist Line. This was followed by another phase of deformation and low-grade metamorphism during the Early Devonian (ca. 405-395 Ma), known as the early Acadian phase in the present-day NE North American and NW European Atlantic margins (Murphy and Keppie, 2005). Clearly then, the Iapetus Ocean first closed in the north (Robert et al., 2020) with continued closure migrating south and resulting in a diachronous collisonal orogeny.
Variscan-Uralian Orogenies and Closure of the Rheic and Uralian Oceans

The closure of the Paleozoic oceans that extended from Mexico to Central Asia gave rise to the Pangea supercontinent. To a certain extent, the resulting orogenies may also include the Acadian and Alleghanian belts in North America, but the main orogenic segment is usually referred to as the Variscan Orogen, which is well documented in Western Europe, from Iberia and Cornwall to Bohemia. The Variscan belt is also represented in basement domains to the Alpine orogen and its structural 


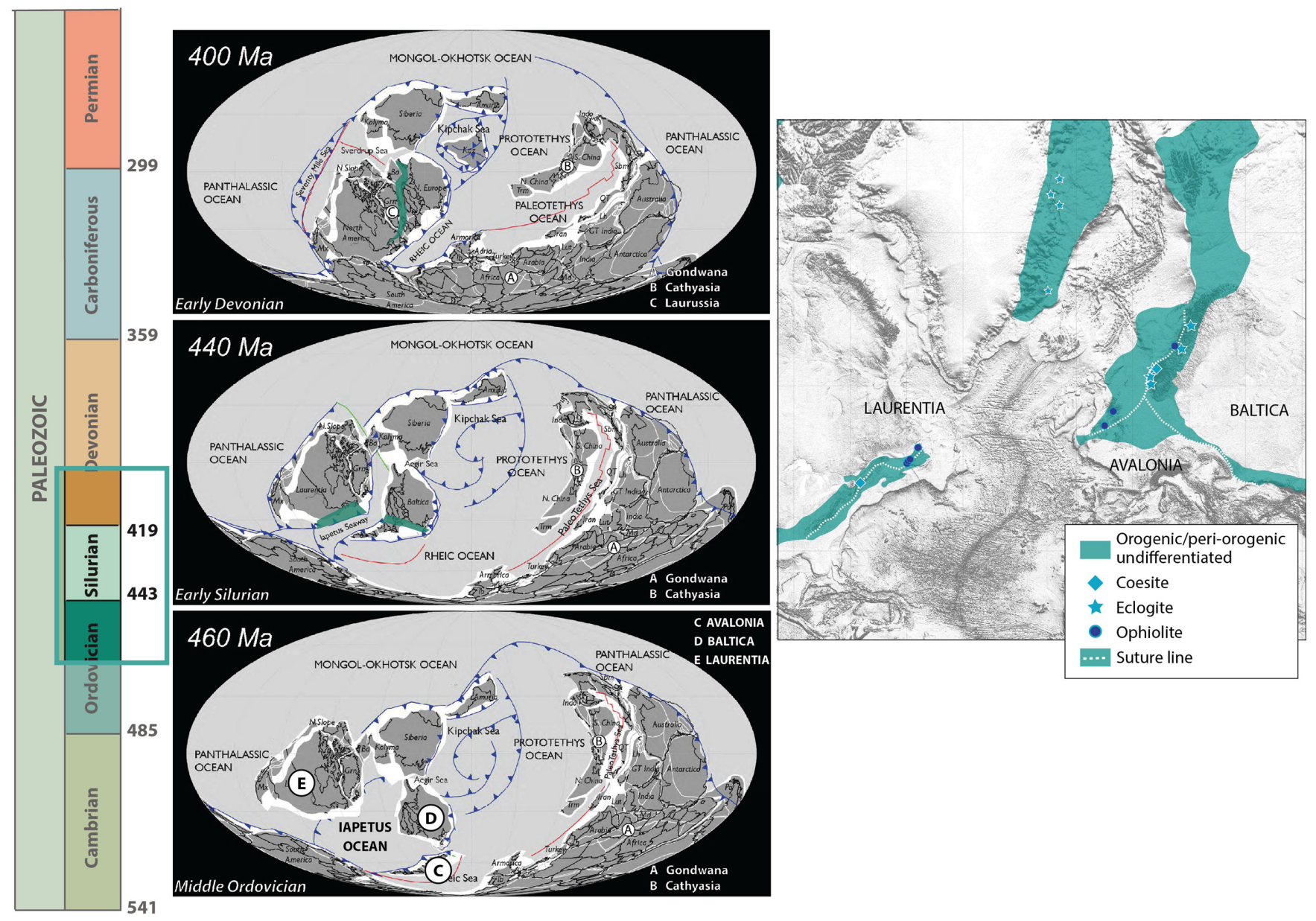

Figure 6. Present location of the Caledonian orogen resulting from the progressive closure of the Iapetus Ocean shown on the World Map and in the past as shown on paleogeographic reconstructions from Scotese, PALEOMAP Project (www.scotese.com).

inheritance was discussed in recent papers (von Raumer et al., 2009; Ballèvre et al., 2018) but remains the subject of debate (von Raumer et al., 2013 and references therein).

The late Acadian Orogeny (375 - $325 \mathrm{Ma}$ ) resulted from the collision of an island arc with Laurussia. It was followed by the Alleghenian Orogeny (325 - $260 \mathrm{Ma}$ ) driven by the collision between Laurussia and Gondwana. Together, both orogens formed the Ouachita and part of the Appalachian Mountains in North America, as well as the Moroccan Meseta and the Anti-Atlas in north-western Africa, a once continuous orogenic belt prior to the opening of the Atlantic Ocean starting in Triassic times (Nance et al., 2010; Michard et al., 2010).

There is no consensus on the basic number of lithospheric plates involved in the Variscan orogeny: two, three or several plates and as many oceans! The Variscan orogen of Southern Britain and Western Europe is related to the closure of several oceanic basins of unknown width between Laurussia in the north and Gondwana in the south (in the present coordinates). Some intervening microcontinents are also recognized between the two large convergent continents (e.g., Pin, 1990; Matte, 2001; Faure et al., 2005, 2008; Ballèvre et al., 2009; Kroner and Romer, 2013; Lardeaux et al., 2014; Franke et al., 2017). In spite of several controversies on the number, the spatial extent and age of the oceanic domains related to the Variscan orogeny, the Saxothuringian and Armorican microcontinents are interpreted as pericra- tonic to the Gondwanian margin - deduced from both the facies and fauna (Robardet, 2003), rifted in the Early Ordovician (ca. 480-460 Ma), and containing evidence of the Neoproterozoic Cadomian orogeny. From the inner to outer parts of Gondwana, three oceanic domains can be recognized. i) The Medio-European (also called Galicia-Massif Central or Galicia-Massif central-Moldanubian) Ocean was probably a small basin similar to the present Red Sea, on the basis of similar benthic faunas on both sides of the ocean. ii) The Tepla-Le Conquet Ocean (Faure et al., 2010) also called Saxo-Thuringian Ocean (Franke et al., 2017) separated the Armorican and Saxothuringian blocks. iii) Lastly, the Rheic Ocean was the main oceanic basin separating Avalonia and Saxothuringia, and the widest due to the presence of different faunal assemblages observed on the Laurussia and Gondwana sides. The timing of closure for these oceanic basins remains disputed. Some authors argue for a poly-orogenic evolution whereas others argue for a monophased collision. In the monocyclic model, all three oceans closed in the Late Devonian-Early Carboniferous, whereas, in the polycyclic model, the Medio-European Ocean was closed by an early oceanic subduction below Armorica. The Gondwana-Armorica Early Devonian collision gave rise to the eo-Variscan belt characterized by HP-UHP metamorphic rocks (eclogites and granulites), SW-directed synmetamorphic nappes, and crustal melting. In the Variscan orogeny, the main collisional event took place when both the Rheic and Tepla-Le Conquet-(Saxo-Thurigian) 
oceans closed after south-directed subduction in Late Devonian-Early Carboniferous, at $c a .360 \mathrm{Ma}$. Late collisional tectono-metamorphic events developed from Visean to Serpukhovian (ca. 335-320 Ma). This deformation produced a doubly-vergent orogen, i.e., north- and south-directed folds and thrusts on the north and south sides of the orogenic belt, respectively. Due to the Permian Ibero-Armorican orocline, the northern foreland developed from the Rheinische Schiefergebirge of eastern Germany, through the Ardennes, SW England, and southern Portuguese zone of Iberia with various displacement directions. The continuity of the southern foreland basin, well exposed in southern France (Massif Central, Pyrenees), SE Spain, and SW Sardinia, was disrupted by the opening of the Provence-Algeria basin in the Neogene. Of interest is the fact that the Paleotethys Ocean is not recognized to the west of Turkey, and therefore did not play a significant role in the formation of the Variscan orogen. However, models of the Variscan orogen based on the Alps suggest the importance of the Paleotethys (Schönlaub, 1993; von Raumer et al., 2013).

The Uralian orogen was the consequence of the Permian closure of the Uralian Ocean between Laurussia in the west and Siberia in the east. The former comprises the subducting plate, whereas the latter was the upper plate, upon which a magmatic arc was built (Puchkov, 2009). The southwestern margin of Baltica defined by the Trans European Suture Zone represents an Early Paleozoic suture (sometimes referred to as the "Polish Caledonides"), possibly reworked by strike- slip faulting in the Late Paleozoic. To the southeast of Baltica, the Uralian orogen formed when Laurussia and Kazakhstania collided with Siberia in the late Carboniferous to early Permian.

The eastern extension of the Variscan orogen in Central Asia remains poorly documented and is beyond the scope of the present contribution. We simply note that the Central Asia Orogenic Belt (CAOB) is the consequence of multiple microcontinent collisions between the Siberia, Tarim, and North China Block (Fig. 7; Sengör et al., 1993; Sengör and Natal'in, 1996; Xiao et al., 2008; Choulet et al., 2012). In addition, another Paleozoic ocean developed at the location of the Kunlun orogen between the Tarim and Qaidam blocks and was connected to poorly deciphered oceans exposed in South China and Indochina (e.g., Faure et al., 2018 and enclosed references).

\section{Alpine Orogeny and Closure of the Neo-Tethys and Alpine Tethys Oceans}

The complex history of the Alpine cycle begins with the opening of the Triassic (Carnian, $220 \mathrm{Ma}$ ) Meliata-Maliac Ocean, followed by the opening of the Vardar Ocean in the Jurassic (Toarcian-Aalenian, $180 \mathrm{Ma}$ ), later referred to as Neo-Tethys (east) and Alpine Tethys oceans (Stampfli, 2000; Bousquet et al., 2008). In the Western Alps, the Liguro-Piemonte ocean opened in Middle Jurassic (CallovianOxfordian). The complexity of the Alpine orogeny comes from the

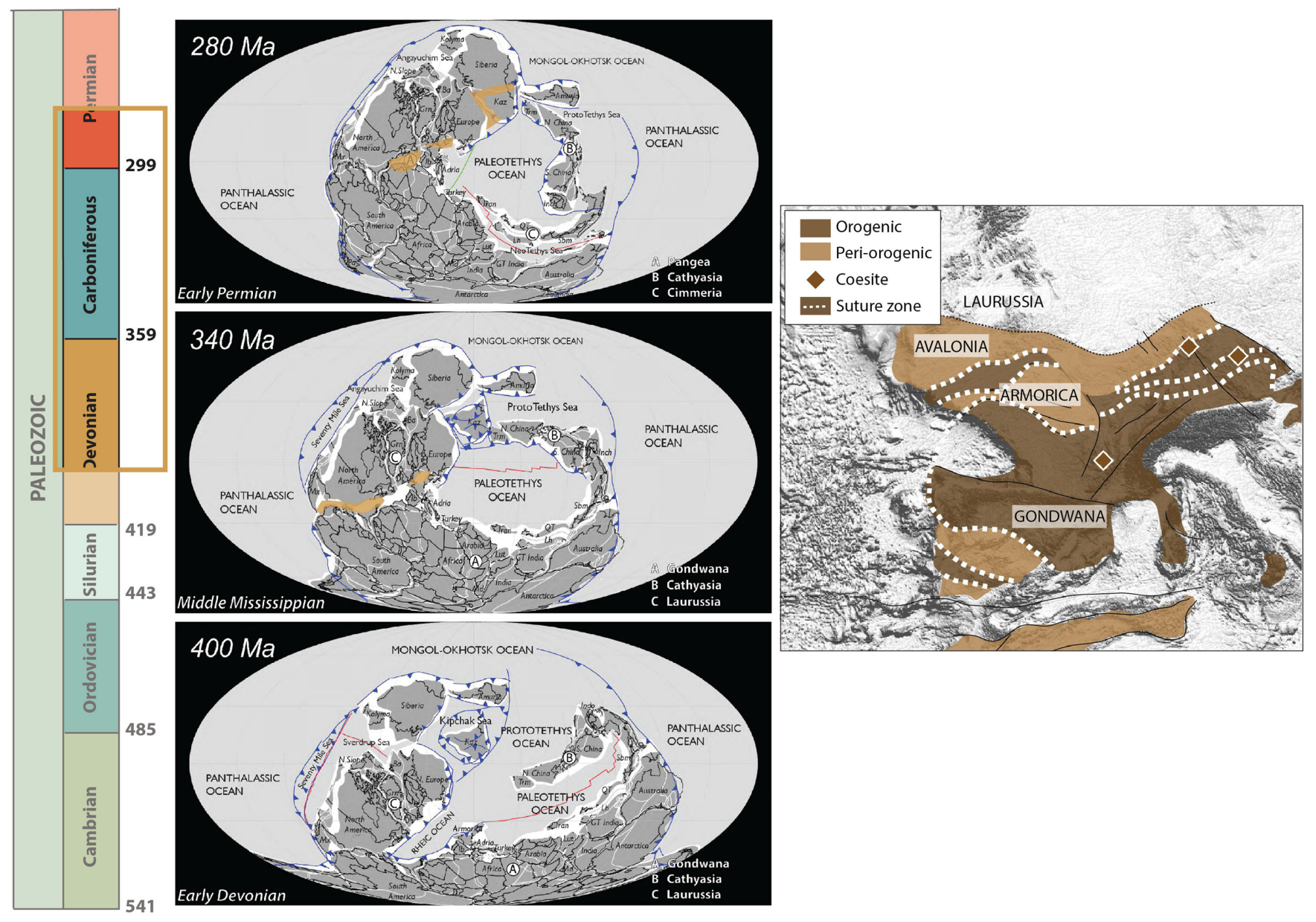

Figure 7. Present location of the Variscan orogens shown on the World Map and in the past as shown on paleogeographic reconstructions from Scotese, PALEOMAP Project (www.scotese.com). 


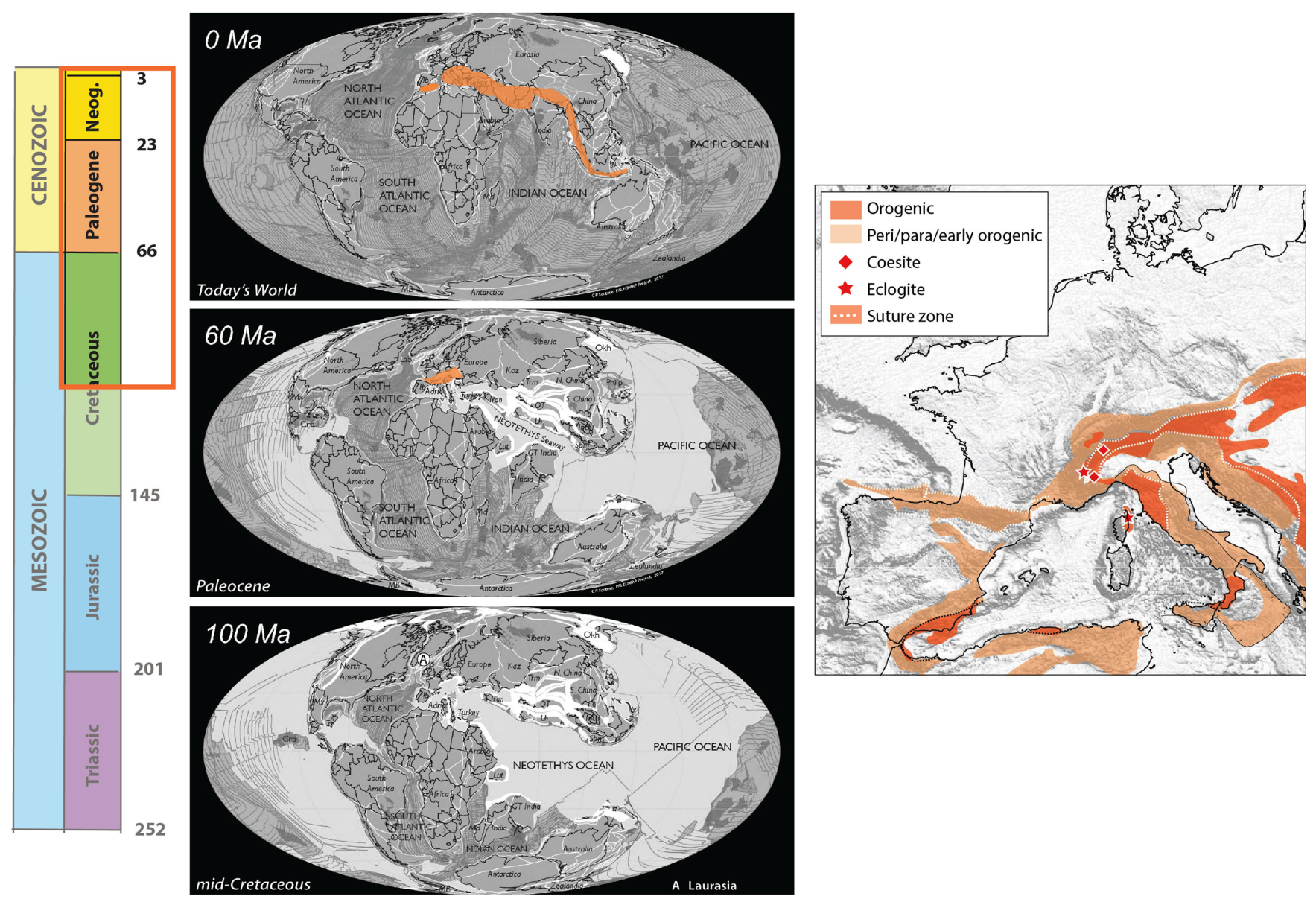

Figure 8. Present location of the Alpine orogens (following closure of the Neo-Tethys and Alpine oceans) shown on the World Map and in the past as shown on paleogeographic reconstructions from Scotese, PALEOMAP Project (www.scotese.com).

fact that its history is intrinsically related to the diachronous closure of two oceanic systems, the Neo-Tethys Ocean (eastern domain) and the Alpine Tethys Ocean (western domain; Stampfli, 2000; Bousquet et al., 2008) when Africa collided with Eurasia. Convergent plate movement began in the Alpine Tethys in the early Cretaceous, but the major phases of mountain building occurred from the Paleocene to the Eocene and continue today (Fig. 8; Handy et al., 2010). The Alpine Orogen sensu lato includes all the Tethyan system from the Moroccan Atlas to the Himalaya.

The Alpine Tethys comprises the Piemont-Liguria Ocean and the Valais Ocean. These are extensions of the Atlantic Ocean continuing eastward into the area of the Circum-Mediterranean orogens during rifting and drifting. The Piemont-Liguria Ocean becomes an extension of the Central Atlantic by Middle Jurassic time. In turn, the Valais Ocean (NW of the Briançonnais microcontinent) forms a Northern Atlantic extension by middle Cretaceous time. The opening of the Piemont-Liguria Ocean led to separation of the Adria plate from the European continent in Callovian-Oxfordian time (165-156 Ma; Schmid et al., 2008) and its closure forms the suture zone between the Austroalpine nappes (derived from Adria) and the Briançonnais microcontinent (derived from Europe). Contemporaneously, the Triassic Meliata-Maliac Ocean subducted southeastward beneath the Jurassic upper plate portions of the Neo-Tethys Ocean (ophiolitic units from Vardar that later formed part of the Dinarides system). By Cretaceous times, the closure of Meliata-Vardar produced the Eastern Alps orogeny (Schmid et al., 2008; Bousquet et al., 2008; Handy et al., 2014).

In Santonian time the two branches of the Alpine Tethys (Valais and Piemont-Liguria) were connected via the Carpathian embayment with the younger part of Neo-Tethys (Cretaceous in age), leading to a back-arc ocean that formed the future Sava Zone of Dinarides, which is considered a remnant of the Vardar Ocean. By Tertiary time, closure of the Alpine Tethys produced the Western and Central Alps orogeny and the Northern Apennines (Bousquet, 2008; Schmid et al., 2008, 2019; Handy et al., 2010, 2014). Further east the CaucasianArabian belt is part of the late Cenozoic Alpine-Himalayan belt. The Trans-European Suture Zone-Kopetdag-Caucasus megafault separates the alpine orogen and the Eurasian plate. The Caucasian-Arabian segment consists of the Greater Caucasus to the north and the Caucasian-Arabian Syntaxis to the south (Sharkov et al., 2015). Greater Caucasus represents the southern margin of the Eurasian plate uplifted over the Main Caucasian Fault (part of the Trans-European Suture Zone-Kopetdag-Caucasus megafault). The Caucasian-Arabian Syntaxis is a zone of indentation of the Arabian plate into the southern East European craton and the Alpine structure of the Caucasus is generated by the interaction of the Arabian indenter and the East European craton. By the late Cenozoic this interaction leads to a 200 to $400 \mathrm{~km}$ shortening of the Caucasian-Arabian Syntaxis (Sharkov et al., 2015).

Therefore, in a tectonic sense the Alpine orogen (lato sensu) is the 
result of two orogenies associated with closure of two oceanic systems: Meliata (part of Neo-Tethys) by the end of Cretaceous time and Alpine Tethys (Atlantic) during Tertiary time.

\section{Key Orogenic Attributes and their Use in a World Map of Orogens}

Due to space and legibility issues, as well as the polycyclic nature of deformation and metamorphism, many orogenic features are difficult to represent on a World Map of Orogens. In order to overcome these constraints, it becomes necessary to identify deformation zones at a regional scale, and to organize them in terms of fundamental components of a "typical" mountain belt. In addition, another issue that requires careful consideration is the spatiotemporal overprint of orogenic events. As outlined in this paper, we have identified key elements of different types of orogens in order to define a number of "typical" orogens and map them on a World map. To do so, we propose the creation of several layers corresponding to time windows that encompass the development of a given orogen. The superposition of these layers allows us to highlight a range of continental growth processes and events through time.

Thus, our approach hinges on the identification of a spatial zonation that is common to many (most?) mountain belts and uses geological concepts that are based on the global rock record. The proposed zonation comprises elements that characterize the architecture of many mountain belts and includes in the internal zone: lower plate "crystalline" metamorphic complexes (often but not always corresponding to older lithostratigraphic substratum) modified by thickskin structures and (U)HP and (U)HT metamorphism, overlain by deformed sedimentary rocks deposited in former distal oceanic areas and possibly ophiolitic slivers of oceanic crust. In contrast, the orogenic upper plate usually contains relics of magmatic arcs and associated (U)HT metamorphism formed prior to collision and ophiolites corresponding to associated back-arc and fore-arc basins. The adjacent foreland domains are devoid of high grade metamorphic assemblages and are generally dominated by thin-skin structures that deform sedimentary strata (Table 1).

Within this broad view of orogenic architecture, there are necessarily additional complexities that can accrue with for example back-thrusting of lithostratigraphic units that result in structurallycomplex domains. Nevertheless, common features such as the direction and polarity of convergence as documented with folds, faults and fold-and-thrust belts can be documented globally. Thus, the proposed zonation (early orogenic, orogenic, peri-orogenic and paraorogenic zones) is useful and certainly reflects key geodynamic processes pertinent to the evolution of orogens through time.

The use of the four-fold classification of orogens is therefore expected to document the growth and modification of continents through time and space since $2.5 \mathrm{Ga}$. We propose to distinguish the various deformation zones (and their components) on the World Map of Orogens with different shades of the same color and thus improve our understanding of the evolution of orogens from early Earth geodynamic processes to current plate tectonic dynamics within a continuum of deformation.

\section{Conclusion}

In the classic Wilson Cycle model, there is a space-time continuum of deformation, during which the various geological elements of a mountain belt system are actively deformed. Since the Wilson Cycle nevertheless treats these elements independently, whereas modern concepts consider the various geodynamic processes to be linked intimately during orogenic evolution, we propose that consideration of the various stages in mountain building may help in the classification of convergent orogens. To a certain extent, this concept in which there is a progression via a propagator from an intracontinental rift to a basin floored with oceanic crust, implies considering inherent links between the various compressional stages, which can be either endmember type (i.e., well-defined spatially and temporarily) or transient (i.e., changing in space and time).

We consider that orogenic zones, which are characterized by (U)HP metamorphism, (U)HT metamorphism, magmatism (aluminous granites) and/or ophiolites (= orogenic zone in types II and III), represent the core of the orogenic system and correspond to what is often referred to as the "internal zone". Such zones can be readily documented in the older orogens even though erosion may have removed much of the higher structural level rock record. On the other hand, the peri-orogenic zones, in which deformation includes fold-thrust belts and lowgrade metamorphism (= peri-orogenic zones in types II and III and early or para-orogenic zones in types I and IV), may have in part (but generally not completely) been eroded in ancient orogens. These are important elements to take in account to achieve a full understanding of the internal architecture of orogens, as well as their sequencing, history, and role in the growth and reorganization of continents with time.

\section{Acknowledgments}

This paper is the result of collaborative discussions within the framework of IGCP project 667 . The project is funded by IUGS via UNESCO and we thank these organizations for their support. We also thank the CGMW for the support provided by their staff and for the organization of meetings. The RMCA is acknowledged for the organization of the 2019 annual meeting in Belgium, Romain Bousquet (Kiel University) for his precious help and his many suggestions for the figures, Solen Le Gardien (SGF) for her help with the references and Benjamin Sautter, Jean-Paul Liégeois and Nadine Ellouz-Zimmermann for their proofreading. The IGCP 667 team is a large group and the name of all the participants can be found with the following link: CGMW/IGCP667 (https://ccgm.org/en/content/11-team). We thank the reviewers for their comments, which improved the content and clarity of the paper greatly. This is NRCan contribution number 20210125.

\section{References}

Abbott, D.H., and Hoffman, S.E., 1984, Archaean plate tectonics revisited 1. Heat flow, spreading rate, and the age of subducting oceanic lithosphere and their effects on the origin and evolution of continents. Tectonics, v. 3, pp. 429-448.

Abbott, D., Burgess, L., Longhi, J., and Smith, W.H.F., 1994, An empiri- 
cal thermal history of the Earth's upper mantle. Journal of Geophysical Research, v. 99, pp. 13835-13850.

Abu Sharib, A.S.A.A., Maurice, A.E., Abd El-Rahman, Y.M., Sanislav, I.V., Schulz, B., and Bakhit, B.R., 2019, Neoproterozoic arc sedimentation, metamorphism and collision: Evidence from the northern tip of the Arabian-Nubian Shield and implication for the terminal collision between East and West Gondwana. Gondwana Research, v. 66, pp. 1342.

Arndt, N. T., and Nisbet, E. G., 1982, Komatiites. Taylor and Francis.

Baldwin, J.A., Bowring, S.A., and Williams, M.L., 2003., Petrological and geochronological constraints on high pressure, high temperature metamorphism in the Snowbird tectonic zone, Canada. Journal of Metamorphic Geology, v. 21, pp. 81-98.

Baldwin, J.A., Bowring, S.A., Williams, M.L. and Williams, I.S., 2004, Eclogites of the Snowbird tectonic zone: petrological and $\mathrm{U}-\mathrm{Pb}$ geochronological evidence for Paleoproterozoic high-pressure metamorphism in the western Canadian Shield. Contributions to Mineralogy and Petrology, v. 147, pp. 528-548.

Ballèvre, M., Bosse, V., Ducassou, C., and Pitra, P., 2009, Palaeozoic history of the Armorican Massif: Models for the tectonic evolution of the suture zones. Comptes rendus géoscience, v. 341, pp. 174-201.

Ballèvre, M., Manzotti, P., and Dal Piaz, G.V., 2018, Pre-Alpine (Variscan) inheritance: a key for the location of the future Valaisan Basin (Western Alps). Tectonics, v. 37, pp. 786-817.

Barrier, E. and Vrielynck, B., 2008, Atlas MEBE - Palaeotectonic Maps of the Middle East (Middle East Basins Evolution Programme). www. CCGM.org

Bastow, I.D., Thompson, D.A., Wookey, J., Kendall, J-M., Helffrich, G., Snyder, D.B., Eaton, D.W., and Darbyshire, F.A., 2011, Precambrian plate tectonics: seismic evidence from northern Hudson Bay, Canada. Geology. v. 39, pp. 91-94.

Beaumont, C., Kamp, P.J.J., Hamilton J., and Fullsack P., 1996, The continental collision zone, South Island, New Zealand. Comparison of geodynamical models and observations. Journal of Geophysical Research, v. 101, pp. 3333-3359. doi:10.1029/95JB02401

Bédard, J.H., 2018, Stagnant lids and mantle overturns: implications for Archaean tectonics, magmagenesis, crustal growth, mantle evolution, and the start of plate tectonics. Geoscience Frontiers, v. 9, pp. 19-49.

Benes, V., Scott, S.D., and Binns, R.A., 1994, Tectonics of rift propagation into a continental margin: western Woodlark Basin, Papua New Guinea. Journal of Geophysical Research: Solid Earth, v. 99, pp. 44394455.

Boniface, N., Schenk, V. and Appel, P., 2012, Paleoproterozoic eclogites of MORB-type chemistry and three Proterozoic orogenic cycles in the Ubendian Belt (Tanzania): Evidence from monazite and zircon geochronology, and geochemistry. Precambrian Research, v. 192, pp. 16-33.

Bousquet, R., Goffé, B., Wiederkehr, M., Koller, F., Schmid, S.M., Schuster, R., Engi, M., and Martinotti, G., 2008, Metamorphism of metasediments at the scale of an orogen: a key to the Tertiary geodynamic evolution of the Alps. Geological Society, London, Special Publications, v. 298, pp. 393-411.

Briais, A., Patriat, P. and Tapponnier, P., 1993, Updated interpretation of magnetic anomalies and seafloor spreading stages in the South China Sea: Implications for the Tertiary tectonics of Southeast Asia. Journal of Geophysical Research: Solid Earth, v. 98, pp. 6299-6328.

Brown, M., 2008, Characteristic thermal regimes of plate tectonics and their metamorphic imprint throughout Earth history: When did Earth first adopt a plate tectonics mode of behavior? When Did Plate Tectonics Begin on Planet Earth? The Geological Society of America, Special Paper, v. 440, pp. 97-128.

Brown, M., and Johnson, T.E., 2018, Invited Centennial Article: Secular change in metamorphism and the onset of global plate tectonics. American Mineralogist. v. 103, pp. 181-196.

Brown, M., Johnson, T., and Gardiner, N. J., 2020, Plate tectonics and the Archean Earth. Annual Review of Earth and Planetary Sciences, v. 48, pp. 291-320.

Bulois, C., Pubellier, M., Chamot-Rooke, N., and Delescluse, M., 2018, Successive rifting events in marginal basins: the example of the Coral Sea region (Papua New Guinea). Tectonics, v. 37, pp. 3-29. doi:10.1002/ 2017TC004783

Cawood, P.A., Kroner, A., and Pisarevsky, S., 2006, Precambrian plate tectonics: criteria and evidence. GSA today, v. 16, p. 4.

Charvet J., Shu L.S., Faure M., Choulet, F., Wang, B., and Le Breton N., 2010, Structural development of the Lower paleozoic belt of South China : genesis of an intracontinental orogen. Journal of Asian Earth Sciences, v. 39, pp. 309-330.

Choulet, F., Faure, M., Cluzel, D., Chen, Y., Lin, W., Wang, B., and Jahn B-M., 2012, Architecture and Evolution of Accretionary Orogens in the Altaids Collage: The Early Paleozoic West Junggar (NW China). American Journal of Science, v. 312, pp. 1098-1145.

Collins, W.J., Van Kranendonk, M.J., and Teyssier, C., 1998, Partial convective overturn of Archaean crust in the east Pilbara Craton, Western Australia: driving mechanisms and tectonic implications. Journal of Structural Geology, v. 20, pp. 1405-1424.

Collins, A.S., Reddy, S.M., Buchan, C., and Mruma, A., 2004, Temporal constraints on Palaeoproterozoic eclogite formation and exhumation (Usagaran Orogen, Tanzania). Earth and Planetary Science Letters, v. 224, pp. 175-192.

Coltice, N., Bertrand, H., Rey, P., Jourdan, F., Phillips, B.R., and Ricard, Y., 2009, Global warming of the mantle beneath continents back to the Archaean. Gondwana Research, v. 15, pp. 254-266.

Coney, P., Jones, D. and Monger, J., 1980, Cordilleran suspect terranes. Nature, v. 288, pp. 329-333. doi:10.1038/288329a0

Corrigan, D., 2012, Paleoproterozoic crustal evolution and tectonic processes: Insight from the LITHOPROBE program in the Trans-Hudson orogeny, Canada: in Percival, J.A., Cook, F., Clowes, R., eds., Tectonic Styles in Canada: The LITHOPROBE Perspective. Geological Association of Canada, Special Paper, v. 49, pp. 237-284.

Corrigan, D., Pehrsson, S., Wodicka, N., and de Kemp, E., 2009. The Palaeoproterozoic Trans-Hudson orogen: a prototype of modern accretionary processes. Geological Society, London, Special Publication, v. 327, pp. 457-479.

Courtillot, V., 1982, Propagating rifts and continental breakup. Tectonics, v. 1. doi:10.1029/TC001i003p00239

d'Acremont, E., Leroy, S., Maia, M., Patriat, P., Beslier, M.O., Bellahsen, N., Fournier, M., and Gente, P., 2006, Structure and evolution of the eastern Gulf of Aden: insights from magnetic and gravity data (EncensSheba MD117 cruise). Geophysical Journal International, Oxford University Press (OUP), v. 165, pp.786-803. doi:10.1111/j.1365-246X.2006. 02950.x

Daly, J.S., Balagansky, V.V., Timmerman, M.J., and Whitehouse, M.J., 2006, The Lapland-Kola orogen: Palaeoproterozoic collision and accretion of the northern Fennoscandian lithosphere. Geological Society, London, Memoirs, v. 32, pp. 579-598.

de Oliveira Chaves, A., and Porcher, C.C., 2020, Petrology, geochemistry and $\mathrm{Sm}-\mathrm{Nd}$ systematics of the Paleoproterozoic Itaguara retroeclogite from São Francisco/Congo Craton: One of the oldest records of the modern-style plate tectonics. Gondwana Research, v. 87, pp. 224-237.

Ding, W., and Li, J., 2016, Propagated rifting in the Southwest Sub-basin, South China Sea: Insights from analogue modelling. Journal of Geodynamics, v. 100, pp.71-86.

Eaton, D.W., and Darbyshire, F., 2010, Lithospheric architecture and tectonic evolution of the Hudson Bay region. Tectonophysics, v. 480, pp. $1-22$.

Elie de Beaumont, M.L., 1852, Notice sur les systèmes des Montagnes. v. 3. Paris. p. 1543.

Evans, D.A.D., and Mitchell, R.N., 2011, Assembly and breakup of the core of Paleoproterozoic-Mesoproterozoic supercontinent Nuna. Geology, v. 39, pp. 443-446.

Evans, D.A.D., Veselovsky, R.V., Petrov, P.Y, Shatsillo, A.V., and Pavlov, 
V.E., 2016, Paleomagnetism of Mesoproterozoic margins of the Anabar Shield: A hypothesized billion-year partnership of Siberia and northern Laurentia. Precambrian Research, v. 281, pp. 639-655.

Faure, M., Be Mézème, E., Duguet, M., Cartier, C., and Talbot, J-Y., 2005, Paleozoic tectonic evolution of medio-Europa from the example of the French Massif Central and Massif Armoricain. In: R. Carosi et al. (eds). Journal of the Virtual Explorer, v. 19. doi:10.3809/jvirtex. 2005. 00120

Faure, M., Bé Mézème, E., Cocherie, A., Rossi, P., Chemenda, A., and Boutelier, D., 2008, Devonian geodynamic evolution of the Variscan Belt, insights from the French Massif Central and Massif Armoricain, Tectonics, v. 27, TC2008. Doi:10.1029/2007TC002115

Faure, M., Sommers, C., Melleton, J., Cocherie, A., and Lautout, O., 2010, The Léon domain (French Massif Armoricain): a westward extension of the Mid-German Crystalline rise? Structural and geochronological insights. International Journal of Earth Sciences, v. 99, pp. 65-81.

Faure, M., Nguyen V.V., Hoai, L.T.T., and Lepvrier, C., 2018, Early Paleozoic or Early-Middle Triassic collision between the South China and Indochina Blocks: the controversy resolved? Structural insights from the Kon Tum massif (Central Vietnam). Journal of Asian Earth Sciences, v. 166, pp. 162-180. doi:10.1016/j.jseaes.2018.07.015

Fletcher, R., Kusznir, N., Roberts, A., and Hunsdale, R., 2013, The formation of a failed continental breakup basin: the Cenozoic development of the Faroe-Shetland Basin. Basin Research, v. 25, pp. 532-553.

Fournier, M., Chamot-Rooke, N., Petit, C., Huchon P., Al-Kathiri, A., Audin, L., Beslier, M-O., d'Acremont, E., Fabbri, O., Fleury, J-M., Khanbari, K., Lepvrier, C., Leroy, S., Maillot, B., and Merkouriev, S., 2010, Arabia-Somalia plate kinematics, evolution of the Aden-Owen-Carlsberg triple junction, and opening of the Gulf of Aden, Journal of Geophysical Reserch, v. 115, B04102. doi:10.1029/2008JB006257

François, C., Philippot, P., Rey, P. and Rubatto, D., 2014, Burial and exhumation during Archean sagduction in the east Pilbara granite greenstone terrane. Earth and Planetary Science Letters, v. 396, pp. 235-251.

François, C., Debaille, V., Paquette, J.L., Baudet, D., and Javaux, E.J., 2018, The earliest evidence for modern-style plate tectonics recorded by HP-LT metamorphism in the Paleoproterozoic of the Democratic Republic of the Congo. Scientific reports, v. 8, pp. 1-10.

Franke, D., Savva, D., Pubellier, M., Steuer, S., Mouly, B., Auxietre, J. L., Meresse, F., and Chamot-Rooke, N., 2014, The final rifting evolution in the South China Sea. Marine and Petroleum Geology, v. 58, pp. 704-720.

Franke, W, Cocks, R.L.M. and Torsvik, T.H., 2017, The Paleozoic Variscan oceans revisited. Gondwana Research, v. 48, pp. 257-284. doi:10.1016/ j.gr.2017.03.005

Frizon de Lamotte, D., Saint Bézar, B., Bracène, R., and Mercier, E., 2000, The two main steps of the Atlas building and geodynamics of the western Mediterranean, Tectonics, v. 19, pp. 740-761.

Gaina, C., Müller, R.D., Royer, J.Y., and Symonds, P., 1999, Evolution of the Louisiade triple junction. Journal of Geophysical Research: Solid Earth, v. 104, pp. 12927-12939.

Ganne, J., De Andrade, V., Weinberg, R.F., Vidal, O., Dubacq, B., Kagambega, N., Naba, S., Baratoux, L., Jessell, M., and Allibon, J., 2012, Modern-style plate subduction preserved in the Palaeoproterozoic West African craton. Nature Geoscience, v. 5, pp. 60-65.

Gapais, D., Cagnard, F., Gueydan, F., Barbey, P., and Ballèvre, M., 2009, Mountain building and exhumation processes through time: inferences from nature and models. Terra Nova, v. 21, pp. 188-94.

Garde, A.A., and Hollis, J.A., 2010, A buried Palaeoproterozoic spreading ridge in the northern Nagssugtoqidian orogen, West Greenland. Geological Society, London, Special Publications, v. 338, pp. 213-234.

Gilbert, G.K., 1890, Lake Bonneville, v. 1. United States Geological Survey.

Goodliffe, A.M., Taylor, B., and Martinez, F., 1999, Data report: Marine geophysical surveys of the Woodlark Basin region. In Proc. ODP, Init. Repts, v. 180, pp. 1-20. College Station, Texas: Ocean Drilling Pro- gram, Texas A\&M University.

Grabau, A., 1924, Stratigraphy of China, part I, Paleozoic and older, Geological Survey of Agriculture and Commerce. Peking, v. 528, pp. 1-6.

Gressly, A., 1840, Observations géologiques sur le Jura Soleurois: Allgemeine Schweizerische Gesellschaft für die Gesamten Naturwissenschaften, Neue Denkschrifte, v. 4, pp. 115-241.

Guiraud, R., and Maurin, J. C., 1992, Early Cretaceous rifts of Western and Central Africa: an overview. Tectonophysics, v. 213, pp. 153-168.

Hall, J., and Dana, J.D., 1873, On some results of the Earth's contraction from cooling, including a discussion of the origin of mountains and the nature of the Earth's interior. Part I, American Journal of Science, v. s3-5, pp. 423-443.

Handy, M.R., Schmid, S.M, Bousquet, R., Kissling, E., and Bernoulli, D., 2010, Reconciling plate-tectonic reconstructions of Alpine Tethys with the geological-geophysical record of spreading and subduction in the Alps. Earth-Science Reviews, v. 102, pp. 121-158. doi:10.1016/j.earscirev.2010.06.002

Handy, M.R., Ustaszewski, K., and Kissling, E., 2014, Reconstructing the Alps-Carpathians-Dinarides as a key to understanding switches in subduction polarity, slab gaps and surface motion. International Journal of Earth Sciences (Geol Rundsch), v. 104, pp. 1-26. doi:10.1007/s00531014-1060-3

Haug, E., 1907, Traité de Géologie: Paris, A. Colin, I, p. 536.

Hernández-Montenegro, J.D., Palin, R.M., Zuluaga, C.A., and HernándezUribe, D., 2021, Archean continental crust formed by magma hybridization and voluminous partial melting. Scientific Reports, v. 11.

Hoffman, P.F., 1988, United Plates of America, the birth of a craton: Early Proterozoic assembly and growth of Laurentia. Annual Review of Earth and Planetary Sciences, v. 16, pp. 543-603.

Howell, D.G., 1989, Tectonics of Suspect Terranes: Mountain Building and Continental Growth, Eds: Chapman and Hall, 1989, Hutchison, C. 2005. Geology of North-West Borneo: Sarawak, Brunei and Sabah: Elsevier, Amsterdam, p. 448.

Jammes, S., Manatschal, G., Lavier, L., and Masini, E., 2009, Tectonosedimentary evolution related to extreme crustal thinning ahead of a propagating ocean: Example of the western Pyrenees, Tectonics, v. 28, pp. $1-24$.

Jaupart, C., Labrosse, S., Mareschal, J.C., 2007, Temperatures, heat and energy in the mantle of the Earth. In: Treatise on Geophysics, v. 7, pp. 253-303.

Kearey, P., 1993, Orogeny in: Kearey, P. The Encyclopedia of the Solid Earth, pp. 443-444. Blackwell, p. 713.

Kolb, J., 2014, Structure of the Palaeoproterozoic Nagssugtoqidian Orogen, South-East Greenland: Model for the tectonic evolution. Precambrian Research, v. 255, pp. 809-822.

Korja, A., Lahtinen, R., and Nironen, M., 2006, The Svecofennian orogen: a collage of microcontinents and island arcs. Geological Society, London, Memoirs, v. 32, pp. 561-578.

Kroner, U., and Romer, R.L., 2013, Two plates-many subduction zones: the Variscan orogeny reconsidered. Gondwana Research, v. 24, pp. 298-329.

Lagabrielle, Y., and Bodinier, J.L., 2008, Submarine reworking of exhumed subcontinental mantle rocks: field evidence from the Lherz peridotites, French Pyrenees. Terra Nova, v. 20, pp. 11-21.

Lahtinen, R., and Huhma, H., 2019, A revised geodynamic model for the Lapland-Kola orogen. Precambrian Research, v. 330, pp. 1-19.

Lardeaux, J.M., Schulmann, K., Faure, M., Janousek, V., Lexa, O., Skrzypek, E., Edel, J-B., and Stipska, P., 2014, The Moldanubian Zone in French Massif Central, Vosges/Schwarzwald and Bohemian Massif revisited: Differences and similarities. In « The Variscan Orogeny: Extent, Timescale and the Formation of the European Crust ». Schulmann, K. et al. (eds). Geological Society, London, Special Publications, p. 405. doi:10.1144/SP405.14

Le Pourhiet, L., Chamot-Rooke, N., Delescluse, M., May, D.A., Watremez, L., and Pubellier, M., 2018, Continental break-up of the South 
China Sea stalled by far-field compression. Nature Geoscience, v. 11, pp. 605-609.

Lesley, J.P., cited in Chamberlin, T.C., and Salisbury, R.D., 1906, Geology, II. Chicago, p. 125.

Lewry, J., and Stauffer, M., 1990, The Early Proterozoic Trans-Hudson Orogen of North America. Geological Association of Canada, Special Paper, p. 37.

Li, Z.X., Li, X.H., Wartho, J.A., Clark, C., Li, W.X., Zhang, C.L., and Bao, C., 2010, Magmatic and metamorphic events during the early Paleozoic Wuyi-Yunkai orogeny, southeastern South China: New age constraints and pressure-temperature conditions. Geological Society of America Bulletin, v. 122, pp. 772-793.

Li, L., Clift, P.D., Stephenson, R., and Nguyen, H.T., 2014, Non-Uniform Hyper-Extension in Advance of Seafloor Spreading on the Vietnam Continental Margin and the SW South China Sea: Basin Research, pp. 106-134. doi:10.1111/bre.12045

Loose, D., and Schenk, V., 2018, 2.09 Ga old eclogites in the EburnianTransamazonian orogen of southern Cameroon: Significance for Palaeoproterozoic plate tectonics. Precambrian Research, v. 304, pp. $1-11$.

Macgregor, A.M., 1951, Some milestones in the Precambrian of Southern Rhodesia. The Transactions and Proceedings of the Geological Society of South Africa, v. 54, pp. 39-50.

Martin, A.K., 1984, Propagating rifts: Crustal extension during continental rifting. Tectonics, v. 3, pp. 611-617.

Martinez, F., Goodliffe, A.M., and Taylor, B., 2001, Metamorphic core complex formation by density inversion and lower-crust extrusion. Nature, v. 411, pp. 930-934.

Mattauer, M., Tapponier, P., Proust, F., 1977, Sur les mécanismes de formation des chaînes intracontinentales. L'exemple des chaînes atlasiques du Maroc, Bulletin de la Société Géologique de France, v. 7, pp. 521-526.

Matte, P., 2001, The Variscan collage and orogeny (480-290 Ma) and the tectonic definition of the Armorica microplate: a review. Terra Nova, v. 13, pp. 122-128.

Meert, J.G., 2002, Paleomagnetic evidence for a Paleo-Mesoproterozoic supercontinent Columbia. Gondwana Research, v. 5, pp. 207-215.

Meert, J.G., 2012, What's in a name? The Columbia (Palaeopangea/Nuna) Supercontinent. Gondwana Research, v. 21, pp. 987-993.

Meert, J.G., and Santosh, M., 2017, The Columbia supercontinent revisited. Gondwana Research, v. 50, pp. 67-83.

Michard, A., Soulaimani, A., Hoepffner, C., Ouanaimi, H., Baidder, L., Rjimati, E.C., and Saddiqi, O., 2010, The South-Western Branch of the Variscan Belt: Evidence from Morocco. Tectonophysics, v. 492, pp. 1-24.

Minshull, T.A., 2009, Geophysical characterisation of the ocean-continent transition at magma-poor rifted margins. Comptes Rendus Geoscience, v. 341, pp. 382-393.

Möller, A., Appel, P., Mezger, K., and Schenk, V., 1995, Evidence for a 2 Ga subduction zone: eclogites in the Usagaran belt of Tanzania. Geology, v. 23, pp. 1067-1070.

Moyen, J-F., Stevens, G., and Kisters, A., 2006, Record of mid-Archaean subduction from metamorphism in the Barberton terrain, South Africa. Nature, v. 442, pp. 559-562.

Müller, S., Dziggel, A., Kolb, J., and Sindern, S., 2018, Mineral textural evolution and PT-path of relict eclogite-facies rocks in the Paleoproterozoic Nagssugtoqidian Orogen, South-East Greenland. Lithos, v. 296, pp. 212-232.

Murphy, J. B., and Keppie, J. D., 2005, The Acadian orogeny in the northern Appalachians. International Geology Review, v. 47, pp. 663-687.

Najman, Y., Jenks, D., Godin, L., Boudagher-Fadel, M., Millar, I., Garzanti, E., Horstwood, M., and Braccial, L., 2017, The Tethyan Himalayan detrital record shows that India-Asia terminal collision occurred by $54 \mathrm{Ma}$ in the Western Himalaya. Earth and Planetary Science Letters, v. 459, pp. 301-310.

Nance, R.D., Gutiérrez-Alonso, G., Keppie, J.D., Linnemann, U., Murphy,
J.B. Quesada, C., Strachan, R.A., and Woodcock, N.A., 2010, Evolution of the Rheic Ocean. Gondwana Research, v. 17, pp. 194-222.

Nutman, A.P., Friend, C.R., and Bennett, V.C., 2002, Evidence for 3650 $3600 \mathrm{Ma}$ assembly of the northern end of the Itsaq Gneiss Complex, Greenland: implication for early Archaean tectonics. Tectonics, v. 21, pp. 5-1.

Nutman, A.P., Dawes, P.R., Kalsbeek, F., and Hamilton, M.A., 2008a, Palaeoproterozoic and Archaean gneiss complexes in northern Greenland: Palaeoproterozoic terrane assembly in the High Arctic. Precambrian Research, v. 161, pp. 419-451.

Nutman, A.P., Kalsbeek, F., and Friend, C.R.L., 2008b, The Nagssugtoqidian orogen in South-East Greenland: evidence for Paleoproterozoic collision and plate assembly. American Journal of Science, v. 308, pp. 529-572.

Palin, R.M., Santosh, M., Cao, W., Li, S.S., Hernández-Uribe, D., and Parsons, A., 2020, Secular metamorphic change and the onset of plate tectonics. Earth-Science Reviews, v. 207, p. 103172.

Park, R.G., 1995, Paleoproterozoic Laurentia-Baltic relationships: a view from the Lewisian, in Coward, M.P., and Ries, A.C., eds., Early Precambrian processes. Geological Society, London, Special Publication, v. 95, pp. 211-224.

Peltonen, P., and Kontinen, A., 2004, The Jormua Ophiolite: a mafic-ultramafic complex from an ancient ocean-continent transition zone. Developments in Precambrian Geology, v. 13, pp. 35-71.

Péron-Pinvidic, G., and Manatschal, G., 2010, From microcontinents to extensional allochthons: witnesses of how continents rift and break apart?. Petroleum Geoscience, v. 16, pp. 189-197.

Pesonen, L.J., Elming, S.Å., Mertanen, S., Pisarevsky, S.A., D’AgrellaFilho, M.S., Meert, J.G., Schmidt, P.W., Abrahamsen, N., and Bylund, G., 2003, Palaeomagnetic configuration of continents during the Proterozoic. Tectonophysics, v. 375, pp. 289-324.

Petrov, O., Shokalsky, S., Pospelov, I., Kashubin, S., Morozov, A., Sobolev, N., Petrov, E., Baluev, A., Sokolov, S., Grikurov, G., Vernikovsky, V., St-Onge, M., Harrison, C., Ernst, R., Guarnieri, P., Labrousse, L., Lemmonier, N., Pubellier, M., Piepjohn, K., Smelror, M., Brekke, H., Faleide, J., Stephens, M., Moore, T., Box, S., Grantz, A., and Orndorff, R., 2018, Tectonic Map of the Arctic: CGMW-VSEGEI, doi:10.14683/2018TEMAR10M

Pin, C., 1990, Variscan oceans: ages, origins and geodynamic implications inferred from geochemical and radiometric data, Tectonophysics, v. 177, pp. 215-227.

Piper, J.D.A., 1976, Paleomagnetic evidence for a Proterozoic supercontinent. Philosophical Transactions of the Royal Society of London, v. A280, pp. 469-490.

Pourteau, A., Candan, O., and Oberhänsli, R., 2010, High-Pressure metasediments in central Turkey: constraints on the Neotethyan closure history. Tectonics, v. 29. doi:10.1029/2009TC002650

Pubellier, M., and Meresse, F., 2013, Phanerozoic Growth of Asia; Geodynamic Processes and Evolution. Journal of Asian Earth Sciences, v. 72, pp. 118-128. doi:10.1016/j.jseaes.2012.06.01

Pubellier, M., Savva, D, Sapin, F., and Aurelio, M., 2017, The Structural Map of the South China Sea at scale 1:3M, Commission for the Geological Map of the World. doi:10.14682/2017STRUCTUSCS

Puchkov, V.N., 2009, The evolution of the Uralian orogen. Geological Society, London, Special Publications, v. 327, pp. 161-195.

Ramos, V.A., 1988, Late Proterozoic-Early Paleozoic of South America: a collisional history. Episodes, v. 11, pp. 168-174.

Ramos, V., 1999, Plate tectonic setting of the Andean Cordillera. Episodes, v. 22, pp. 183-190.

Richardson, S.H., and Shirey, S.B., 2011, Subcontinental mantle evidence for the onset of plate tectonics at $3 \mathrm{Ga}$ in relation to Earth's thermal evolution. AGU Fall Meeting Abstracts, v. 2011, pp. U44A-08.

Robardet, M., 2003, The Armorica 'microplate': fact or fiction? Critical review of the concept and contradictory palaeobiogeographical data. Palaeogeography, Palaeoclimatology, Palaeoecology, v. 195, pp. 125- 
148.

Robert, B., Domeier, M., and Jakob, J., 2020, Iapetan Oceans: An analog of Tethys? Geology, v. 48, pp. 929-933.

Robert, C., and Bousquet, R., 2018, Geowissenschaften: Die Dynamik des Systems Erde. Springer-Spektrum, p. 1016.

Rogers, H.D., 1858, The geology of Pennsylvania, II: Edinburgh, Blackwood, 1045.

Schmidd S.M., Bernouilli, D., Fügenschuh, B., Mattenco, L., Schefer, S., Schuster, R., Tischler, M. and Ustaszewski, K., 2008, The Alpine-Carpathian-Dinaridic orogenic system; correlation and evolution of tectonic units. Swiss Journal of Geosciences, v. 101, pp. 139-183. doi: 10.1007/s00015-008-1247-3

Schmid, S.M., Fügenschuh, B., Kounov, A., Maţenco, L., Nievergelt, P., Oberhänsli, R., Pleuger, J., Schefer, S., Schuster, R., Tomljenović, B., Ustaszewski, K., and Van Hinsbergen, D.J., 2019, Tectonic units of the Alpine collision zone between Eastern Alps and western Turkey, Gondwana Research, v. 78, pp. 308-374. https://doi.org/10.1016/j.gr.2019.07.005

Schönlaub, H.P., 1993, Stratigraphy, biogeography and climatic relationships of the Alpine Palaeozoic. In Pre-Mesozoic geology in the Alps. Springer, Berlin, Heidelberg, pp. 65-91.

Scotese, C.R., 1991, Jurassic and Cretaceous plate tectonic reconstructions. Palaeogeography, Palaeoclimatology, Palaeoecology, v. 87, pp. 493-501.

Scotese, C.R., 2016, PALEOMAP Paleo Atlas for GPlates and the Paleo Data Plotter Program, PALEOMAP Project, http://www.earthbyte.org/ paleomap-paleoatlas-for-gplates/

Scott, D.J., Helmstaedt, H., and Bickle, M.J., 1992, Purtuniq ophiolite, Cape Smith belt, northern Quebec, Canada: A reconstructed section of Early Proterozoic oceanic crust. Geology, v. 20, pp. 173-176.

Sengör, A.M.C., and Okurogullari, A.H., 1991, The role of accretionary wedges in the growth of continents-asiatic examples from argand to plate-tectonics. Eclogae geologicae helvetiae, v. 84, pp. 535-531.

Sengör, A.M.C., and Natal'in, B.A., 1996, Paleotectonics of Asia: fragments of a synthesis. In: Yin, A., Harrison, M. (Eds.), The Tectonic Evolution of Asia. Cambridge University Press, Cambridge, pp. 486-640.

Sengör, A.M.C., Natal'in, B.A., and Burtman, V.S., 1993, Evolution of the Altaid tectonic collage and Palaeozoic crustal growth in Eurasia. Nature, v. 364, pp. 299-307.

Seton, M., Müller, R.D., Zahirovic, S., Gaina, C., Torsvik, T., Shephard, G., Talsma, A., Gurnis, M., Turner, M., Maus, S., and Chandler, M., 2012a, Global continental and ocean basin reconstructions since 200 Ma. Earth-Science Reviews, v. 113, pp. 212-270.

Seton, M., Zahirovic, S., and Müller, R., 2012b, The tectonic evolution of Southeast Asia through accretionary and extensional episodes since the Cretaceous. AGU Fall Meeting Abstracts, v. 2012, pp. T51D-2629.

Sharkov, E., Lebedev, V., Chugaev, A., Zabarinskaya, L., Rodnikov, A., Sergeeva, N. and Safonova, I., 2015, The Caucasian-Arabian segment of the Alpine-Himalayan collisional belt: Geology, volcanism and neotectonics. Geoscience Frontiers, pp. 503-522.

Shirey, S.B., Kamber, B.S., Whitehouse, M.J., Mueller, P.A., and Basu, A.R., 2008, A review of the isotopic and trace element evidence for mantle and crustal processes in the Hadean and Archean: Implications for the onset of plate tectonic subduction. When did plate tectonics begin on planet Earth?, v. 440, p. 1.

Sibuet, J.C., Yeh, Y.C., and Lee, C.S., 2016, Geodynamics of the south China sea. Tectonophysics, v. 692, pp. 98-119.

Skublov, S.G., Astaf'ev, B.Y., Marin, Y.B., Berezin, A.V., Mel'nik, A.E., and Presnyakov, S.L., 2011, New data on the age of eclogites from the Belomorian mobile belt at Gridino settlement area. In Doklady Earth Sciences, v. 439, pp. 1163-1170.

Slabunov, A.I., Volodichev, O.I., Skublov, S.G. and Berezin, A.V., 2011, Main stages of the formation of paleoproterozoic eclogitized gabbronorite: Evidence from U-Pb (SHRIMP) dating of zircons and study of their genesis. In Doklady Earth Sciences, v. 437, p. 396.

Smithies, R., Champion, D. and Cassidy, K., 2003, Formation of Earth's early Archaean continental crust. Precambrian Research, v. 127, pp.
89-101.

Smooth, C., 2012, Tectonic Globaloney: Closing Arguments. Author House. p. 158.

Snoeyenbos, D.R., Williams, M.L., and Hanmer, S., 1995, Archean highpressure metamorphism in the western Canadian Shield. European Journal of Mineralogy-Ohne Beihefte, v. 7, pp. 1251-1272.

Stampfli, G.M., 2000, Tethyan oceans. Geological Society of London Special Publications, v. 173, pp. 1-23.

Stampfli, G.M. and Borel, G.D., 2002, A plate tectonic model for the Paleozoic and Mesozoic constrained by dynamic plate boundaries and restored synthetic oceanic isochrons. Earth and Planetary Science Letters, v. 196, pp. 17-33.

Stille, H., 1920, Die Begriffe Orogenese und Epirogenese: Zeitschrift der Deutschen Geologischen Gesellschaft Band, v. 71, pp. 164-240.

Stille, H., 1940, Einführung in den Bau Amerikas: Berlin, Borntraeger, p. 717.

St-Onge, M.R., Searle, M.P., and Wodicka, N., 2006, Trans-Hudson orogen of North America and Himalaya-Karakoram-Tibetan orogen of Asia: structural and thermal characteristics of the lower and upper plates. Tectonics, v. 25, pp. 1-22.

St-Onge, M.R., Wodicka, N., and Ijewliw, O., 2007, Polymetamorphic evolution of the Trans-Hudson Orogen, Baffin Island, Canada: Integration of petrological, structural and geochronological data. Journal of Petrology, v. 48, pp. 271-302.

St-Onge, M.R., Van Gool, J.A.M., Garde, A.A., and Scott, D.J., 2009, Correlation of Archaean and Palaeoproterozoic units between northeastern Canada and western Greenland: constraining the pre-collisional upper plate accretionary history of the Trans-Hudson orogen. Geological Society, London, Special Publication, v. 318, pp. 193-235.

St-Onge, M.R., Scott, D.J., Rayner, N., Sanborn-Barrie, M., Skipton, D.R., Saumur, B.M., Wodicka, N., and Weller, O.M., 2020, Archean and Paleoproterozoic Cratonic Rocks of Baffin Island: In "Baffin Island and the Labrador-Baffin Seaway Geological Synthesis". (ed.) L.T. Dafoe and N. Bingham-Koslowski. Geological Survey of Canada Bulletin, v. 608, pp. 01-29.

Strachan R.A., and Woodcock N.H., 2021, The Tectonic Pattern of Britain and Ireland. In: Alderton, David; Elias, Scott A. (eds.) Encyclopedia of Geology, 2nd edition, v. 4, pp. 328-337. United Kingdom: Academic Press.

Suess, E., 1893, Are Great Ocean Depth Permanent? Natural Science, 2180-187.

Tang, M., Lee, C-T.A., Rudnick, R.L., and Condie, K.C., 2019, Rapid mantle convection drove massive crustal thickening in the late Archean. Geochimica et Cosmochimica Acta, v. 278, pp. 6-15. doi:10.1016/ j.gca.2019.03.039

Taylor, B., Goodliffe, A.M., and Martinez, F., 1999, How continents break up: insights from Papua New Guinea. Journal of Geophysical Research: Solid Earth, v. 104, pp. 7497-7512.

Taylor, B., and Hayes, D.E., 1983, Origin and history of the South China Sea basin. The tectonic and geologic evolution of Southeast Asian seas and islands: Part 2, v. 27, pp. 23-56.

Taylor, S.R., and McLennan, S.M., 1985, The Continental Crust: Its Composition and Evolution. Blackwell Scientific Publication, Carlton, p. 312. OSTI ID: 6582885.

Taylor, B., Goodliffe, A., Martinez, F., and Hey, R., 1995, Continental rifting and initial sea-floor spreading in the Woodlark Basin. Nature, v. 374, pp. 534-537.

Thébaud, N., and Rey, P.F., 2013, Archean gravity-driven tectonics on hot and flooded continents: controls on long-lived mineralised hydrothermal systems away from continental margins. Precambrian Research, v. 229 , pp. 93-104.

Thompson, D.A., Bastow, I.D., Helffrich, G., Kendall, J-M., Wookey, J., Snyder, D.B., and Eaton, D.W., 2010, Precambrian crustal evolution: seismic constraints from the Canadian Shield. Earth and Planetary Science Letters, v. 297, pp. 655-666. 
Thurmann, M. J., 1854, Résumé des lois orographiques générales du système des monts Jura. Bulletin de la Société Géologique de France, v. 2, pp. 41-57.

Tugend, J., Manatschal, G., Kusznir, N.J., Masini, E., Mohn, G., and Thinon, I., 2014, Formation and deformation of hyperextended rift systems: Insights from rift domain mapping in the Bay of Biscay-Pyrenees. Tectonics, v. 33, pp. 1239-1276. doi:10.1002/2014TC003529

Upham, W., 1894, Wave-like progress of an epeirogenic uplift. The Journal of Geology, v. 2, pp. 383-395.

Van der Pluijm, B.A., and Marshak, S., 2004, Earth structure. New York.

Van Gool, J.A.M., Connelly, J.N., Marker, M., and Mengel, F.C., 2002, The Nagssugtoqidian Orogenof West Greenland: Tectonic evolution and regional,correlations from a West Greenland perspective. Canadian Journal of Earth Sciences, v. 39, pp. 665-686.

Van Kranendonk, M.J., Collins, W.J., Hickman, A., Pawley, M.J., 2004, Critical tests of vertical vs. horizontal tectonic models for the Archaean East Pilbara granite-greenstone terrane, Pilbara craton, Western Australia. Precambrian Research, v. 13, pp. 173-211.

Volodichev, O.I., Slabunov, A.I., Bibikova, E.V., Konilov, A.N., and Kuzenko, T.I., 2004, Archean eclogites in the Belomorian mobile belt, Baltic Shield. Petrology, v. 12, pp. 540-560.

Von Raumer, J.F., Bussy, F., and Stampfli, G.M., 2009, The Variscan evolution in the External massifs of the Alps and place in their Variscan framework. Comptes Rendus Geoscience, v. 341, pp. 239-252.

Von Raumer, J.F., Bussy, F., Schaltegger, U., Schulz, B., and Stampfli, G.M., 2013, Pre-Mesozoic Alpine basements - their place in the European Paleozoic framework. Bulletin, v. 125, pp. 89-108.

Wan, B., Yang, X., Tian, X., Yuan, H., Kirscher, U., and Mitchell, R.N., 2020, Seismological evidence for the earliest global subduction network at $2 \mathrm{Ga}$ ago. Science Advances, v. 6, p. eabc5491.

Wang, Y., Fan, W., Zhang, G., and Zhang, Y., 2013, Phanerozoic tectonics of the South China Block: key observations and controversies. Gondwana Research, v. 23, pp. 1273-1305.

Weissel, J.K., and Watts, A.B., 1979, Tectonic evolution of the Coral Sea basin. Journal of Geophysical Research: Solid Earth, v. 84, pp. 45724582.

Weller, O.M., and St-Onge, M.R., 2017, Record of modern-style plate tectonics in the Palaeoproterozoic Trans-Hudson orogeny. Nature Geoscience, v. 10, pp. 305-313.

Weller, O.M., Jackson, S., Miller, W.G.R., St-Onge, M.R., and Rayner, N., 2020, Quantitative elemental mapping of granulite-facies monazite: Textural insights and implications for petrochronology. Journal of Metamorphic Geology, v. 38, pp. 853-880.

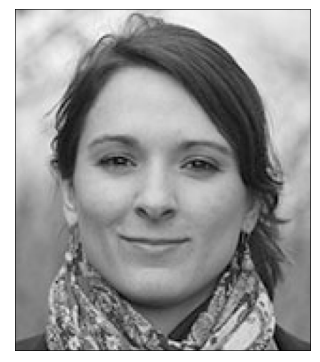

Camille François is a researcher on Earth Sciences at the Commission for the Geological Map of the World, Paris (France). She received a PhD in Earth Sciences (2014) at Institut Physique du Globe de Paris, France and the Sydney University, Australia. She worked as lecturer and postdoctoral researcher at the University of Liège (Belgium), where she developed geochronological methods on Precambrian sedimentary sequences containing microfossils. Her specialties are Precambrian metamorphic rocks and their significance for geodynamics through Earth history. Her current research focuses on markers of orogens through time and on the mapping of orogens worldwide.
Wilson, R.W., Houseman, G.A., Buiter, S.J.H., McCaffrey, K.J.W. and Doré, A.G. 2019. Fifty years of the Wilson Cycle Concept in Plate Tectonics: an Overview. Geological Society, London, Special Publications, pp. 1-17. doi:10.1144/SP470-2019-58

Windley, B., 1992, Proterozoic collisional and accretionary orogens. In Developments in Precambrian Geology, Elsevier, v. 10, pp. 419-446.

Windley, B.F., Kusky, T., and Polat, A., 2020, Onset of plate tectonics by the Eoarchean. Precambrian Research, p. 105980.

Xiao, W.J., Han, C.M., Yuan, C., Sun, M., Lin, S.F., Chen, H.L., Li, Z.L., Li, J.L., and Sun, S., 2008, Middle Cambrian to Permian subductionrelated accretionary orogenesis of North Xinjiang, NW China: implications for the tectonic evolution of Central Asia. Journal of Asian Earth Sciences, v. 32, pp. 102-117.

Xin, Y., Li, J., Ratschbacher, L., Zhao, G., Zhang, Y., Dong, S., Xia, X-P., and Yu, Y., 2020, Early Devonian (415-400 Ma) A-type granitoids and diabases in the Wuyishan, eastern Cathaysia: A signal of crustal extension coeval with the separation of South China from Gondwana. GSA Bulletin, v. 132, pp. 2295-2317.

Xu, C., Kynický, J., Song, W., Tao, R., Lü, Z., Li, Y., and Fei, Y., 2018, Cold deep subduction recorded by remnants of a Paleoproterozoic carbonated slab. Nature communications, v. 9, p. 2790.

Yao, W., Li, Z.X., and Li, W.X., 2014, Was there a Cambrian ocean in South China? - Insight from detrital provenance analyses. Geological Magazine, v. 152, pp. 184-191.

Yu, H.L., Zhang, L.F., Wei, C.J., Li, X.L., and Guo, J.H., 2017, Age and P$\mathrm{T}$ conditions of the Gridino-type eclogite in the Belomorian Province, Russia. Journal of Metamorphic Geology, v. 35, pp. 855-869.

Zhao, G., and Cawood, P.A., 1999, Tectonothermal evolution of the Mayuan assemblage in the Cathaysia Block: implications for Neoproterozoic collision-related assembly of the South China Craton. American Journal of Science, v. 299, pp. 309-339.

Zhao, G., Cawood, P.A., Wilde, S.A., and Sun, M., 2002, Review of global 2.1-1.8 Ga orogens: implications for a pre-Rodinia supercontinent. Earth-Science Reviews, v. 59, pp. 125-162.

Zhao, G., Li, S., Sun. M., and Wilde, S.A., 2011, Assembly, accretion, and break-up of the Palaeo-Mesoproterozoic Columbia supercontinent: record in the North China Craton revisited. International Geology Review, v. 53, pp. 1331-1356.

Ziegler, P.A., 1990, Tectonic and palaeogeographic development of the North Sea rift system. In Tectonic evolution of the North Sea rifts, pp. $1-36$.

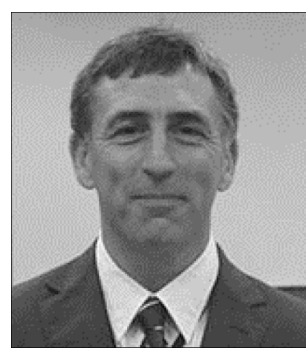

Manuel Pubellier is a Research Director in Earth Sciences at CNRS (Ecole Normale Supérieure-Paris-Sorbonne University (France) He received $\mathrm{ahD}$ in Tectonics (1987) at the University Pierre et Marie Curie, Paris, France. His expertise is Geodynamics and Structural Geology of margins onshore and offshore, Imagery and seismic interpretation. His current research focuses on oblique convergent margins in SE Asia (Philippines, Indonesia New Guinea, Burma) and the Caribbean. He is the President of the Commission for the Geological Map of the World since 2018. 


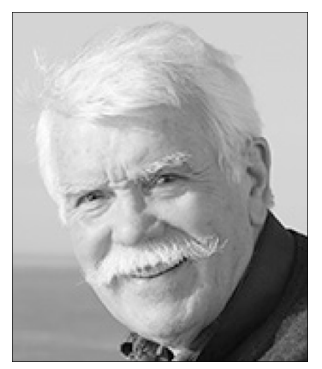

Christian Robert is a professor of Earth Sciences in the CNRS/ Ecole Normale Supérieure de Paris (France). He received a $\mathrm{PhD}$ in Geosciences (1981) at the University Pierre et Marie Curie, Paris, France. His specialty is metamorphism, including experimental practice and fieldwork in different orogenic contexts (American Cordilleras, Ireland, Alps). By combining his research activities and his interest in teaching, he has naturally become involved, for many years, in preparing students for competitive examinations for secondary education. He is author of around twenty educational and scientific publications in the form of articles, geological maps or excursion guide.

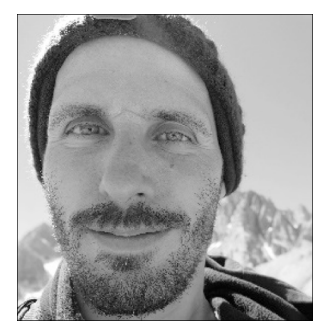

Cédric Bulois is currently a postdoctoral fellow at Institut de Recherche et Développement (Valbonne, France) where he works on the structural evolution of the EcuadorPeru segment of the Northern Andes margin. After a few years in Ireland as a research assistant, he received a $\mathrm{PhD}$ in Marine Geosciences (2016) from Ecole Normale Supérieure (Paris, France) and Université de Bretagne Occidentale (Brest, France) focussing on the rift propagation processes. His expertise are fault dynamics and associated reactivation processes, basin stratigraphy, and climate reconstruction and forcing, in both rift and orogenic systems. He is also strongly involved in various other research and teaching projects in France, Ireland and Haiti.

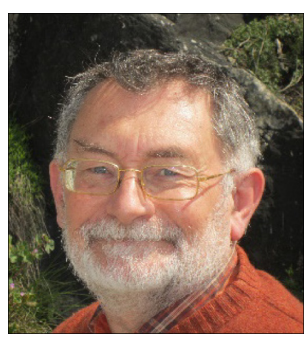

Michel Faure is emeritus professor of Geology in the University of Orléans (France). $\mathrm{He}$ received $\mathrm{PhD}$ in Geosciences at the University of Orléans (1985), and University of Tokyo (1986). He is dealing with continental crust deformation including metamorphic evolution, crustal melting, and ore deposits in orogens. He is involved in the study of several mountain belts of Asia, namely Paleozoic and Mesozoic Japan, Paleozoic belt of SE China, Qinling-Dabie, Chinese Tianshan, Paleoproterozoic of N. China, Indosinian orogens of Vietnam, and S. China, and European Variscan orogeny. He authored around 250 scientific publications, wide-audience articles or excursion guide-books, and supervised around $30 \mathrm{PhD}$ students. He is associate-editor of the Journal of Asian Earth Sciences, and Comptes Rendus Geoscience.

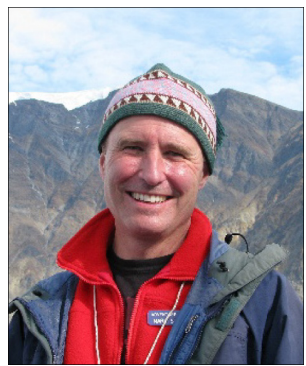

Marc St-Onge is Senior Emeritus Scientist at the Geological Survey of Canada, Visiting Professor at Oxford University, and Visiting Senior Scholar at Cambridge University. He received a PhD in Geology and Metamorphic Petrology (1981) from Queen's University, Kingston, Canada. He has lead geological mapping expeditions to study unknown or little-known destinations and phenomena in remote parts of the world, from the Canadian Arctic to western Greenland, northwest Scotland, the Himalaya of Pakistan, India and Nepal and the Tibetan Plateau in China. His documented contributions to scientific exploration and geological field research are evidenced by the publication of over 120 journal articles and reports, and 119 geological maps. He is Vice-President (North and Central America Sub-commission) at the Commission for the Geological Map of the World since 2012. 